\title{
The HDM2 (MDM2) Inhibitor NVP-CGM097 Inhibits Tumor Cell Proliferation and Shows Additive Effects with 5-Fluorouracil on the p53-p21-Rb-E2F1 Cascade in the p53wild type Neuroendocrine Tumor Cell Line GOT1
}

\author{
Reuther, Clemens ; Heinzle, Vera ; Nölting, Svenja ; Herterich, Sabine ; Hahner, Stefanie ; Halilovic, \\ Ensar ; Jeay, Sébastien ; Wuerthner, Jens U ; Aristizabal Prada, Elke Tatjana ; Spöttl, Gerald ; \\ Maurer, Julian ; Auernhammer, Christoph J
}

\begin{abstract}
BACKGROUND/AIMS The tumor suppressor p53 is depleted in many tumor cells by the E3 ubiquitin ligase mouse double minute 2 homolog (MDM2) through MDM2/p53 interaction. A novel target for inhibiting p53 degradation and for causing reexpression of p53wild type is inhibition of MDM2. The small molecule NVP-CGM097 is a novel MDM2 inhibitor. We investigated MDM2 inhibition as a target in neuroendocrine tumor cells in vitro. METHODS Human neuroendocrine tumor cell lines from the pancreas (BON1), lung (NCI-H727), and midgut (GOT1) were incubated with the MDM2 inhibitor NVP-CGM097 (Novartis) at concentrations from 4 to 2,500 nM. RESULTS While p53wild type GOT1 cells were sensitive to NVP-CGM097, p53mutated BON1 and p53mutated NCI-H727 cells were resistant to NVP-CGM097. Incubation of GOT1 cells with NVP-CGM097 at 100, 500, and 2,500 nM for $96 \mathrm{~h}$ caused a significant decline in cell viability to $84.9 \pm 9.2 \%(\mathrm{p}<0.05), 77.4 \pm 6.6 \%(\mathrm{p}<0.01)$, and 47.7 $\pm 9.2 \%(\mathrm{p}<0.01)$. In a Western blot analysis of GOT1 cells, NVP-CGM097 caused a dose-dependent increase in the expression of p53 and p21 tumor suppressor proteins and a decrease in phospho-Rb and E2F1. Experiments of co-incubation of NVP-CGM097 with 5-fluorouracil, temozolomide, or everolimus each showed additive antiproliferative effects in GOT1 cells. NVP-CGM097 and 5-fluorouracil increased p53 and p21 expression in an additive manner. CONCLUSIONS MDM2 inhibition seems a promising novel therapeutic target in neuroendocrine tumors harboring p53wild type. Further investigations should examine the potential role of MDM2 inhibitors in neuroendocrine tumor treatment.
\end{abstract}

DOI: https://doi.org/10.1159/000453369

Posted at the Zurich Open Repository and Archive, University of Zurich

ZORA URL: https://doi.org/10.5167/uzh-208189

Journal Article

Published Version

Originally published at:

Reuther, Clemens; Heinzle, Vera; Nölting, Svenja; Herterich, Sabine; Hahner, Stefanie; Halilovic, Ensar; Jeay, Sébastien; Wuerthner, Jens U; Aristizabal Prada, Elke Tatjana; Spöttl, Gerald; Maurer, Julian; Auernhammer, Christoph J (2018). The HDM2 (MDM2) Inhibitor NVP-CGM097 Inhibits Tumor Cell Proliferation and Shows Additive Effects with 5-Fluorouracil on the p53-p21-Rb-E2F1 Cascade in the p53wild type Neuroendocrine Tumor Cell Line GOT1. Neuroendocrinology, 106(1):1-19.

DOI: https://doi.org/10.1159/000453369 
Nenro

endocrinology
Neuroendocrinology 2018;106:1-19

DOI: $10.1159 / 000453369$
Received: June 20, 2016

Accepted after revision: November 11, 2016

Published online: November 21, 2016

\title{
The HDM2 (MDM2) Inhibitor NVP-CGM097 \\ Inhibits Tumor Cell Proliferation and Shows Additive Effects with 5-Fluorouracil on the p53-p21-Rb-E2F1 Cascade in the p53 wild type Neuroendocrine Tumor Cell Line GOT1
}

\author{
Clemens Reuther $^{a} \quad$ Vera Heinzle $^{a}$ Svenja Nölting ${ }^{a}$ Sabine Herterich ${ }^{b}$ \\ Stefanie Hahner ${ }^{b}$ Ensar Halilovic ${ }^{c}$ Sébastien Jeay ${ }^{c}$ Jens U. Wuerthner ${ }^{c}$ \\ Elke Tatjana Aristizabal Prada ${ }^{a}$ Gerald Spöttl ${ }^{\mathrm{a}} \quad$ Julian Maurer ${ }^{\mathrm{a}}$ \\ Christoph J. Auernhammer ${ }^{a}$ \\ a Department of Internal Medicine II, Campus Grosshadern, University Hospital, Ludwig Maximilian \\ University of Munich, Munich, and ${ }^{b}$ University Hospital, Julius Maximilian University of Würzburg, \\ Würzburg, Germany; ${ }^{c}$ Novartis, Basel, Switzerland
}

\section{Keywords}

MDM2 inhibitor · NVP-CGM097 · p53 · p21 · 5-Fluorouracil ·

Temozolomide · Everolimus · Neuroendocrine tumor · GOT1

\begin{abstract}
Background/Aims: The tumor suppressor p53 is depleted in many tumor cells by the $\mathrm{E} 3$ ubiquitin ligase mouse double minute 2 homolog (MDM2) through MDM2/p53 interaction. A novel target for inhibiting p53 degradation and for causing reexpression of $\mathrm{p} 53^{\text {wild type }}$ is inhibition of MDM2. The small molecule NVP-CGM097 is a novel MDM2 inhibitor. We investigated MDM2 inhibition as a target in neuroendocrine tumor cells in vitro. Methods: Human neuroendocrine tumor cell lines from the pancreas (BON1), lung ( $\mathrm{NCl}-\mathrm{H} 727)$, and midgut (GOT1) were incubated with the MDM2 inhibitor NVP-CGM097 (Novartis) at concentrations from 4 to 2,500 nM. Results: While p53 wild type GOT1 cells
\end{abstract}

\section{KARGER}

๑ 2016 S. Karger AG, Basel

E-Mail karger@karger.com

www.karger.com/nen were sensitive to NVP-CGM097, p53 $3^{\text {mutated }}$ BON1 and p53 mutated $\mathrm{NCl}-\mathrm{H} 727$ cells were resistant to NVP-CGM097. Incubation of GOT1 cells with NVP-CGM097 at 100,500, and $2,500 \mathrm{nM}$ for $96 \mathrm{~h}$ caused a significant decline in cell viability to $84.9 \pm 9.2 \%(p<0.05), 77.4 \pm 6.6 \%(p<0.01)$, and $47.7 \pm 9.2 \%(p<0.01)$. In a Western blot analysis of GOT1 cells, NVP-CGM097 caused a dose-dependent increase in the expression of $\mathrm{p} 53$ and $\mathrm{p} 21$ tumor suppressor proteins and a decrease in phospho-Rb and E2F1. Experiments of coincubation of NVP-CGM097 with 5-fluorouracil, temozolomide, or everolimus each showed additive antiproliferative effects in GOT1 cells. NVP-CGM097 and 5-fluorouracil increased p53 and p21 expression in an additive manner. Conclusions: MDM2 inhibition seems a promising novel therapeutic target in neuroendocrine tumors harboring p53 $3^{\text {wild type }}$. Further investigations should examine the potential role of MDM2 inhibitors in neuroendocrine tumor treatment.

(c) 2016 S. Karger AG, Basel

Christoph J. Auernhammer, Department of Internal Medicine II

University Hospital Campus Grosshadern, Interdisciplinary Center for Neuroendocrine Tumors of the GastroEnteroPancreatic System (GEPNET-KUM)

Ludwig Maximilian University of Munich, Marchioninistrasse 15

DE-81377 Munich (Germany)

E-Mail christoph.auernhammer@med.uni-muenchen.de 


\section{Introduction}

Neuroendocrine neoplasias of the gastroenteropancreatic system and the lung are heterogeneous tumors [1]. Molecular targeted therapy is one systemic treatment option for neuroendocrine tumors (NETs) [2-7]. Currently, the mTOR inhibitor everolimus [8] and the multi-tyrosine kinase inhibitor sunitinib (VEGFR, PDGFR, KIT) [9] are both approved for the treatment of pancreatic NETs. Everolimus has also recently been approved for gastrointestinal and lung NET treatment [10]. Inhibition of growth signaling and angiogenetic factors is one common strategy for targeting multiple cancers including NETs [2].

Another promising strategy seems to be the induction of reexpression and reactivation of tumor suppressors such as p53 in cancers [11]. Functional loss of the tumor suppressor p53 is observed in many tumors, either by inactivating mutations of $\mathrm{p} 53$ or by degradation of p53 $3^{\text {wild type }}$ mediated by negative regulators such as the E3 ubiquitin ligase mouse double minute 2 homolog (MDM2) or MDM4 (MDMX). Overexpression of the negative p53 regulators MDM2 or MDM4 is found in many tumors and causes inactivation of p53 [11]. The E3 ubiquitin ligase MDM2 associates with the tumor suppressor p53 and causes inactivation of p53 by ubiquitin-dependent protein degradation of the MDM2-p53 protein complex [11]. In addition, MDM2 also has been reported to exert additional, p53-independent effects such as p21 degradation, $\mathrm{Rb}$ degradation, FOXO3a degradation, E-cadherin degradation, or X-linked inhibitor of apoptosis protein (XIAP) accumulation [12]. The effect of MDM2 overexpression in tumor cells thus might contribute to loss of cell cycle regulation, inhibition of apoptosis, and induction of epithelial-mesenchymal transition [12]. MDM2 inhibitors aim to inhibit MDM2-p53 interaction and thus prevent p53 degradation and reactivate functional p53 $3^{\text {wild type }}$ expression [12]. Inhibition of MDM2 by small molecules seems to be a promising novel strategy for targeted therapy in oncology [11-14]. The small molecule inhibitor NVP-CGM097 is a novel MDM2 inhibitor [15-17] which binds to human MDM2 with a $K_{\mathrm{i}}$ value of $1.3 \mathrm{nM}$ [15].

MDM2 inhibition has recently been discussed as a potential treatment strategy in NETs due to several circumstances $[18,19]$. NETs frequently overexpress p53 inhibitors, as copy number gains in MDM2, MDM4, and p53 $3^{\text {wild type }}$-induced phosphatase 1 (WIP1) have been found in NETs of pancreatic origin in 22, 30, and $51 \%$ of the cases, respectively [20]. On the other hand, NETs of small intestinal and pancreatic origin have been shown to exhibit only a low $(<5 \%)$ frequency of somatic TP53 gene mutations $[21,22]$. Thus, the majority of NETs harbors the wild-type TP53 gene and might be sensitive to reactivation of $\mathrm{p} 53^{\text {wild type }}$ by MDM2 inhibitors. Increased aberrant immunohistochemical p53 staining in cancers is commonly accepted as an indicator of TP53 mutations causing accumulation of nonfunctional p53 [20, 23-26]. Accordingly, high aberrant staining levels of p53 as assessed by immunohistochemistry have been demonstrated as a predictor of poor prognosis in various carcinomas [27-30]. TP53 mutations are a rare event in well-differentiated NETs [21, 22]. Thus, no aberrant expression of p53 immunohistochemical staining is expected in welldifferentiated NETs. Accordingly, in a large series of NETs of the pancreas, Hu et al. [20] demonstrated immunohistochemically positive staining for the $\mathrm{p} 53$ downregulators MDM2 in 61\% (104/171), MDM4 in 57\% (98/171), and WIP1 in 58\% (99/171) of the cases, while immunohistochemical positivity for p53 was not observed in any $(0 / 101)$ of the tumor samples investigated. In neuroendocrine gastroenterointestinal neoplasms, aberrant staining levels of p53 in immunohistochemistry have been reported in $0-17.6 \%$ of well-differentiated colorectal NETs, versus $88-100 \%$ of poorly differentiated neuroendocrine carcinomas [26, 31]. In neuroendocrine lung tumors, p53 protein staining results were positive in $0 \%(0 / 47)$ of typical carcinoids and in $11 \%(1 / 9)$ of atypical carcinoids, but in $68 \%(36 / 53)$ of large- and small-cell neuroendocrine carcinomas of the lung [32]. TP53 mutations are a rare event in pulmonary carcinoids, but they are highly frequent in small-cell lung carcinomas and large-cell neuroendocrine lung carcinomas of the lung $[33,34]$.

Expression of $\mathrm{p} 53^{\text {wild type }}$ has been demonstrated to be a major indicator of tumor cell response to MDM2 inhibition [35]. Low/absent p21 expression has also been reported to be a negative prognostic indicator in gastroenteropancreatic NETs [36] and lung NETs [32]. Thus, upregulation of p21 expression by MDM2 inhibition might be another promising target.

Currently, there are only preliminary preclinical data regarding the effects of MDM2 inhibitors on NET cell lines $[18,19]$. Therefore, we aimed to investigate in vitro the effects of the MDM2 inhibitor NVP-CGM097 (Novartis) on human NET cells of small intestinal (GOT1), pancreatic (BON1), and bronchial (NCI-H727) origin. For the first time, we demonstrate MDM2 inhibition by NVP-CGM097 to be antiproliferative in $\mathrm{p} 53^{\text {wild type }}$ GOT1 tumor cells and to show additive effects with 5-fluorouracil, temozolomide, or everolimus (RAD001) in this preclinical NET model.
$2 \quad$ Neuroendocrinology 2018;106:1-19 DOI: $10.1159 / 000453369$
Reuther et al. 


\section{Materials and Methods}

\section{Materials}

Dulbecco's modified Eagle's medium-Nutrient Mixture F-12 (1:1; DMEM/F12) and penicillin/streptomycin were purchased from Gibco/Invitrogen (Karlsruhe, Germany), trypsin-EDTA $(10 \times)$ was acquired from PAA Laboratories (Cölbe, Germany), phosphate-buffered saline (PBS) and RPMI medium (with L-glutamine, $\mathrm{NaHCO}_{3}$ ) were purchased from Sigma-Aldrich (St. Louis, MO, USA), and fetal bovine serum (FBS) and amphotericin B were from Biochrom (Berlin, Germany). NVP-CGM097 and everolimus were provided by Novartis (Basel, Switzerland). Octreotide, 5-fluorouracil, streptozotocin, and temozolomide were purchased from Selleckchem (Munich, Germany). The APO-One ${ }^{\circledR}$ homogeneous caspase 3/7 assay was purchased from Promega (Mannheim, Germany).

\section{Cell Cultures}

All human neuroendocrine cell lines were received and cultured as recently described [37]. The human pancreatic NET cell line BON1 [38, 39] (kindly provided by Prof. R. Göke, Marburg, Germany) was grown in DMEM/F12 (1:1) supplemented with $10 \%$ FBS, $1 \%$ penicillin/streptomycin, and $0.4 \%$ amphotericin $\mathrm{B}$. Human midgut carcinoid GOT1 cells [40] (kindly provided by Prof. O. Nilsson, Sahlgrenska University Hospital Gothenburg, Sweden) and human bronchopulmonary neuroendocrine NCIH727 tumor cells $[41,42]$ (purchased from ATCC, Manassas, VA, USA) were cultured in RPMI medium supplemented with $10 \%$ FBS, $1 \%$ penicillin/streptomycin, and $0.4 \%$ amphotericin B. The hepatocellular carcinoma cell lines HepG2 (purchased from ATCC) and Huh7 (acquired from JCRB Cell Bank, Osaka, Japan) were cultured in RPMI medium supplemented with $10 \%$ FBS, $1 \%$ penicillin/streptomycin, and $0.4 \%$ amphotericin B. The cells were mycoplasma free and incubated at $37^{\circ} \mathrm{C}$ in $5 \% \mathrm{CO}_{2} /$ $95 \%$ air.

\section{Assessment of Cell Viability}

Cells were seeded at appropriate densities (BON1 cells: 1,500 cells/well; NCI-H727 cells: 2,000 cells/well; GOT1 cells: 50,000 cells/well) into 96-well plates and grown for $24 \mathrm{~h}$ in complete medium containing serum/antibiotic. The next day, the cells were incubated with various concentrations of NVP-CGM097 (0.1$12,500 \mathrm{nM}), 5$-fluorouracil (100 $\mathrm{nM}$ to $100 \mu \mathrm{M})$, streptozotocin (1 nM to $100 \mu \mathrm{M})$, temozolomide ( $1 \mu \mathrm{M}$ to $1 \mathrm{mM})$, everolimus ( $10 \mathrm{nM})$, or octreotide (100 nM to $10 \mu \mathrm{M}$ ) in $10 \%$ FBS medium (antibiotic free). After 48, 96, 144, or 216 h, the metabolic activity was measured with the Cell Titer 96 Aqueous One Solution cell proliferation assay (Promega, Madison, WI, USA) according to the manufacturer's instructions. The measurement was performed at 492 $\mathrm{nm}$ with an ELISA plate reader.

\section{Protein Extraction and Western Blotting}

For Western blot experiments, $1 \times 10^{6}$ GOT1 cells, $4 \times 10^{5}$ BON1 cells, or $5 \times 10^{5} \mathrm{NCI}-\mathrm{H} 727$ cells were seeded in 6-well plates and grown for $24 \mathrm{~h}$ in complete medium. After the medium had been replaced by fresh 10\% FBS medium, the cells were incubated with several concentrations of NVP-CGM097 (20-2,500 nM) for 2 and $24 \mathrm{~h}$. The cells were placed on ice, washed twice with cold PBS, and lysed in $200 \mu \mathrm{L}$ lysis buffer (M-PER ${ }^{\circledR}$ Mammalian Protein Extraction Reagent containing HALT ${ }^{\mathrm{TM}}$ protease and phosphatase inhibitor cocktail; Thermo Fisher Scientific, Rockford, IL, USA). The lysates were centrifuged at 13,000 rpm for $10 \mathrm{~min}$. The supernatants were adjusted to the same protein concentration $(30-50$ $\mu \mathrm{g} / 50 \mu \mathrm{L}$; Roti ${ }^{\circledR}$-Quant universal; Carl Roth, Karlsruhe, Germany). Sodium dodecyl sulfate (SDS) sample buffer $(0.25 \mathrm{M}$ Tris $\mathrm{HCl}$, $40 \%$ glycerol, $2 \%$ SDS, $1 \%$ dithiothreitol, and bromophenol blue, $\mathrm{pH}$ 8.8) was added, and the samples were boiled for $5 \mathrm{~min}$ and separated on an SDS polyacrylamide gel. Proteins were electrotransferred for 60 min onto PVDF membranes (Immobilone; Millipore, Eschborn, Germany) using a semi-dry Western blot technique. After blocking in $2 \%$ nonfat dried milk, the membranes were incubated overnight in appropriate dilutions of antibodies against p4EBP1 Ser65 (\#9451), 4EBP1 (\#9644), pAkt S473 (\#4060), Akt (\#4691), pAMPK Thr172 (\#2535), AMPK (5831), BclxL (\#2764), Bid (\#2002), CDK2 (\#2546), CDK4 (\#12790), CDK6 (\#13331), pCREB Ser133 (\#9198), CREB (\#9197), cyclin B1 (\#12231), cyclin D3 (\#2936), Daxx (\#4533), E2F-1 (\#3742), pEGFR Tyr1068 (\#3777), EGFR (\#4267), pErk1/2 Thr202/Tyr204 (\#4370), HAUSP (\#4833), HSP90 (\#4877), pMDM2 Ser166 (\#3521), MGMT (\#2739), pmTOR Ser2448 (\#2971), mTOR (\#2972), PCNA (\#5624), Puma (\#12450), pRb Ser780 (\#8180), Rb (\#9313), pS6 S240/4 (\#5364), S6 (\#2217) (all Cell Signaling, Danvers, MA, USA), MDM2 (700555) (Invitrogen, Darmstadt, Germany), p21 Waf1/ Cip1 (610233) (BD Transduction Laboratories, Heidelberg, Germany), cyclin E (sc-481), p53 (sc-126) (both Santa Cruz, Dallas, TX, USA), actin (A5441) (Sigma-Aldrich), and Erk1/2 (06-182) (Merck-Millipore, Darmstadt, Germany).

After washing with TBS, the membranes were incubated with a peroxidase-conjugated secondary antibody $(1: 25,000)$ for $2 \mathrm{~h}$. The blots were washed and immersed in the chemiluminescent substrate SuperSignal West Dura (Thermo Fisher Scientific) and images were taken with an ECL ChemoCam Imager (Intas Science Imaging Instruments, Göttingen, Germany).

\section{Cell Cycle Analysis by FACS}

Cell cycle analysis by FACS was performed as recently described [43], using propidium iodide (PI) staining and flow cytometry (BD Accuri C6 Analysis). GOT1 cells $\left(3 \times 10^{5}\right.$ cells/well) were cultured for $24 \mathrm{~h}$ in complete medium. The next day, the medium was replaced with fresh 10\% FBS medium and incubated with NVP-CGM097 (1-3 $\mu \mathrm{M})$, 5-fluorouracil (10 $\mu \mathrm{M})$, and octreotide $(10 \mu \mathrm{M})$. After $72 \mathrm{~h}$, the cells were washed with PBS and treated with $300 \mu \mathrm{L}$ trypsin at $37^{\circ} \mathrm{C}$ for $4 \mathrm{~min}$. The cells were collected and centrifuged at 2,000 rpm for $5 \mathrm{~min}$. After another wash cycle with PBS, the cells were centrifuged again. The pellets were resuspended in $350 \mu \mathrm{L}$ PI. After $2 \mathrm{~h}$, the samples were measured.

\section{Caspase Activity Assay}

GOT1 cells $\left(1 \times 10^{5}\right.$ cells/well $)$ were incubated with NVPCGM097 (1-3 $\mu \mathrm{M}), 5$-fluorouracil $(10 \mu \mathrm{M})$, and octreotide $(10 \mu \mathrm{M})$ for $72 \mathrm{~h}$. Afterwards, caspase activity was measured with the APOOne ${ }^{\circledR}$ homogenous caspase $3 / 7$ assay (Promega, Mannheim, Germany) following the manufacturer's instructions.

\section{DNA Isolation and TP53 Sequencing}

Cells were seeded at appropriate densities $\left(1 \times 10^{6}\right.$ GOT 1 cells, $4 \times 10^{5}$ BON1 cells, or $5 \times 10^{5}$ NCI-H727 cells) in $10-\mathrm{cm}$ dishes and grown in complete medium until they reached a semi-confluent state. DNA extraction was performed with a DNA extraction kit (Quiagen).
NVP-CGM097 Inhibits Tumor Cell

Proliferation in NET Cell Line GOT1
Neuroendocrinology 2018;106:1-19

DOI: $10.1159 / 000453369$ 
Table 1. Primer pairs for the PCR-based amplification of exons $5-10$ of the TP53 gene ( $5^{\prime}-3^{\prime}$ direction)

\begin{tabular}{ll}
\hline P53_5F TGTTCACTTGTGCCCTGACTT & P53_5R AACCAGCCCTGTCGTCTCTC \\
P53_6F GCCTCTGATTCCTCACTGAT & P53_6R TGGAGGGCCACTGACAACCA \\
P53_7F CCTCATCTTGGGCCTGTGTT & P53_7R AGTGTGCAGGGTGGCAAG \\
P53_8F AGGACCTGATTTCCTTACTGC & P53_8R TGCACCCTTGGTCTCCTCCAC \\
P53_Ex8_9_Fw GCCTCTTGCTTCTCTTTTCC & P53_Ex8_9_Rev AAAACGGCATTTTGAGTGTT \\
P53_Ex10_Fw TCAAACAATTGTAACTTGAACCATC & P53_Ex10_Rev AAGGCAGGATGAGAATGGAA
\end{tabular}

PCR-based amplification of exons 5-10 of the TP53 gene was performed with forward and reverse primers as shown in Table 1. PCR was performed in a total volume of $25 \mu \mathrm{L}$ containing $200 \mu \mathrm{M}$ dNTPs, 2.5 pmol primers, $1 \mu \mathrm{L} \mathrm{DNA}(20 \mathrm{ng} / \mu \mathrm{L})$, and $2.5 \mu \mathrm{L} 10$-fold buffer $(500 \mathrm{mM} \mathrm{KCl}, 100 \mathrm{mM}$ Tris- $\mathrm{HCl}[\mathrm{pH}=8.3$ ], $0.25 \%$ Tween 20, and $15 \mathrm{mM} \mathrm{MgCl}_{2}$ ). PCR was performed as follows: $96^{\circ} \mathrm{C}$ for 2 min; 30 cycles of $96^{\circ} \mathrm{C}$ for $30 \mathrm{~s}, 58^{\circ} \mathrm{C}$ for $30 \mathrm{~s}$, and $72^{\circ} \mathrm{C}$ for $1 \mathrm{~min}$; and a final step of $72^{\circ} \mathrm{C}$ for $5 \mathrm{~min}$.

PCR products were cleaned by EXO/SAP digestion (ExoSap IT, Affymetrix). Sequencing was performed with the Q-Kit (Beckman Coulter, Krefeld, Germany) and sequencing products were separated on the CEQ 8000 system (Beckman Coulter).

\section{Statistical Analysis}

For proliferation assays, comparisons were evaluated using the 2 -tailed Student $t$ test. Results are expressed as means \pm SD of 3 or 4 independently performed experiments. Statistical significance was set at $p<0.05$.

\section{Results}

Human NET Cell Lines Show Differential Expression of p53, p21, MDM2, Rb, E2F1, and MGMT

Cells were grown under basal conditions in complete medium. Western blot analysis demonstrated a differential baseline expression of the tumor suppressor p53 in human pancreatic neuroendocrine BON1, bronchopulmonary NCI-H727, and midgut GOT1 tumor cells (Fig. 1). While NCI-H727 cells showed a high expression level, GOT1 cells showed a low expression level of p53 protein at the expected $54-\mathrm{kDa}$ band (Fig. 1). In contrast, BON1 cells showed expression of a different $50-\mathrm{kDa}$ protein band (Fig. 1), most probably due to a truncated protein version. The different NET cell lines also demonstrated differential expression levels of MDM2, Rb, and E2F1 (Fig. 1).

MGMT ( $\mathrm{O}^{6}$-methylguanine DNA methyltransferase) expression could not be detected in any of the 3 NET cell lines, while MGMT was strongly expressed in control cells, e.g., in hepatocellular carcinoma HepG2 and Huh7 cells (Fig. 1).

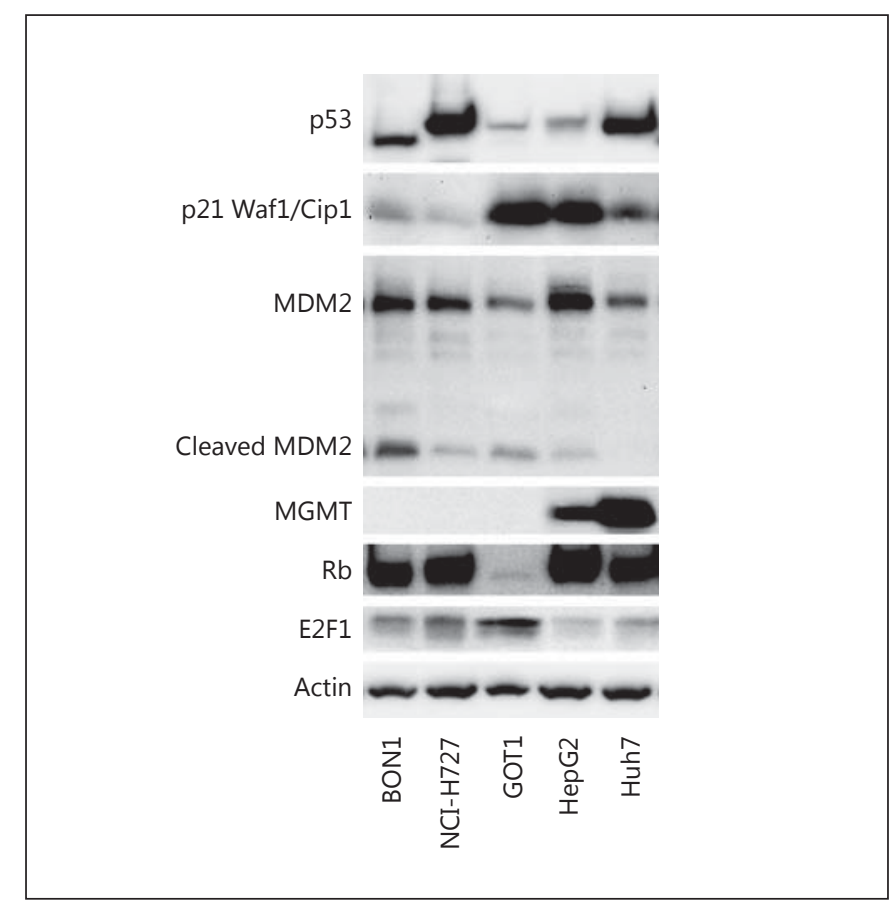

Fig. 1. Western blot analysis of baseline protein expression in human pancreatic neuroendocrine BON1, bronchopulmonary NCIH727, and midgut GOT1 tumor cells. The hepatocellular carcinoma cell lines HepG2 and Huh7 were used as controls. Expression levels of p53, p21, MDM2, Rb, E2F1, MGMT, and actin are displayed. A representative blot out of 3 independently performed experiments is shown.

\section{The Human NET Cell Lines BON1 and NCI-H727}

\section{Harbor TP53 Gene Mutations}

Only approximately $5 \%$ of all somatic TP53 mutations have been reported to be located in exons $2-4$, introns, and the promoter region of TP53, respectively, whereas approximately $90 \%$ of all somatic mutations in TP53 have been reported to be located in exons 5-8 [44] (IARC TP53 Database, version R17, November 2013; http://p53.iarc.fr). Therefore, a sequencing analysis of exons 5-10 of the TP53 gene was performed in DNA
Reuther et al. 


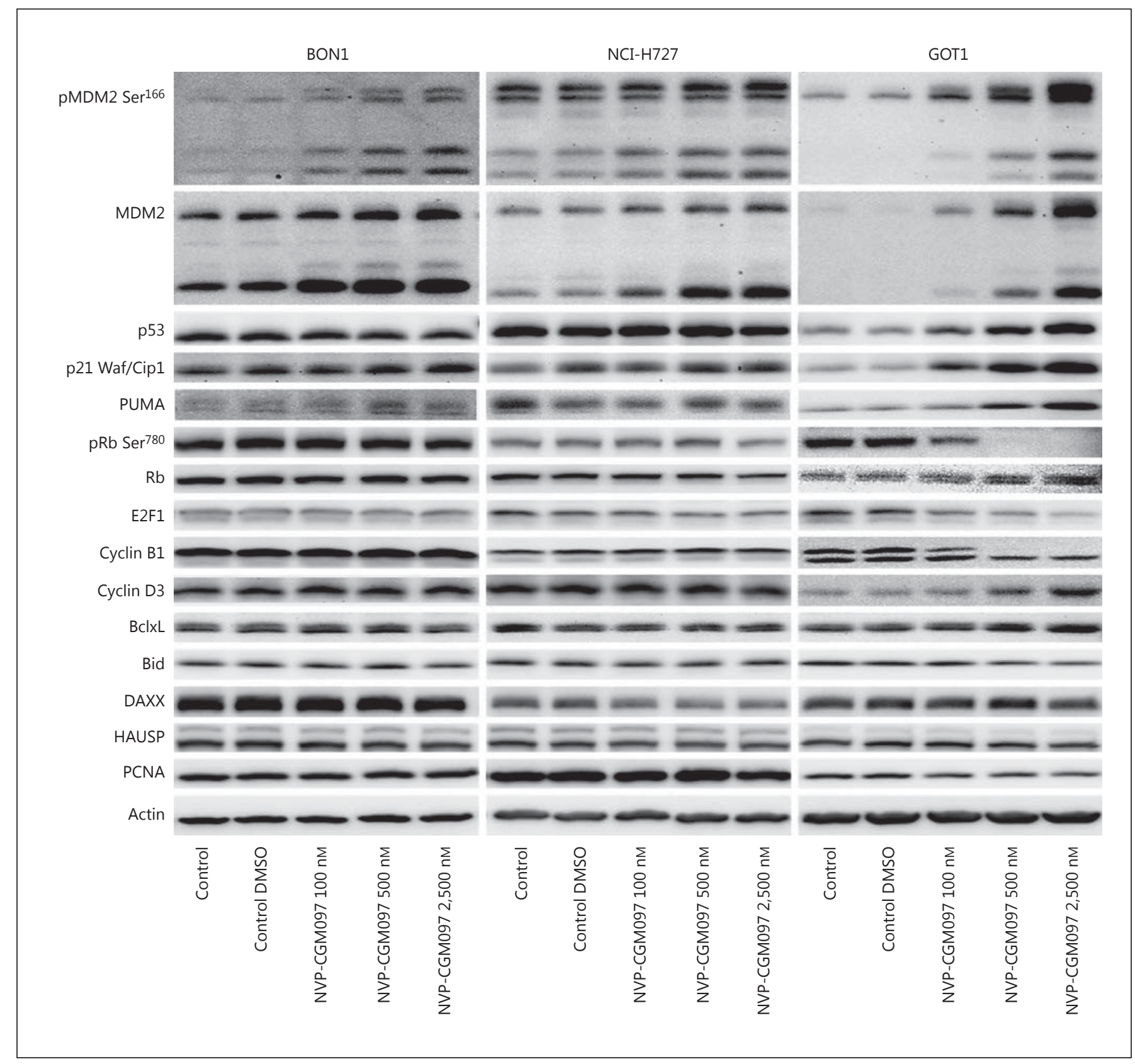

Fig. 2. Western blot analysis of pMDM2, MDM2, p53, p21, PUMA, pRb, Rb, E2F1, cyclin B1, cyclin D3, BclxL, Bid, DAXX, HAUSP, PCNA, and actin in p53 $3^{\text {wild type }}$ GOT1 cells, p53 $3^{\text {mutated }}$ BON1, and p53 mutated NCI-H727 cells during 48-h incubation with the MDM2 inhibitor NVP-CGM097. Western blot signal acquisition times with the ECL ChemoCam Imager were individually optimized for each of the cell lines investigated. A representative blot out of 3 independently performed experiments is shown.

derived from human pancreatic neuroendocrine BON1, bronchopulmonary NCI-H727, and midgut GOT1 tumor cells.

GOT1 cells showed no mutations in the TP53 gene, indicating a functional $\mathrm{p} 53^{\text {wild type }}$ protein. In contrast,
TP53 mutations with putative loss of function of p53 $3^{\text {mutated }}$ were found in BON1 and NCI-H727 cells. BON1 cells demonstrated a p.R342Stop $(c .1024 \mathrm{C}>\mathrm{T})$ in exon 10 of the TP53 gene (online suppl. Fig. 1A; see www. karger.com/doi/10.1159/000453369 for all online suppl.
NVP-CGM097 Inhibits Tumor Cell Proliferation in NET Cell Line GOT1
Neuroendocrinology 2018;106:1-19 DOI: $10.1159 / 000453369$ 
material). This preliminary stop codon in TP53 explains the truncated p53 protein expressed in BON1 cells (online suppl. Fig. 1). NCI-H727 cells demonstrated a heterozygous 9-bp insertion (c.492_493ins9) in exon 5 (online suppl. Fig. 1B), causing a tandem duplication of amino acids 163-164-165 (online suppl. Fig. 1C).

The MDM2 Inhibitor NVP-CGM097 Increases the Expression of $p 53$ and of Its Known Downstream Targets MDM2, pMDM2, 21 , and PUMA, and Decreases the Expression of phospho-Rb and E2F1 in GOT1 Tumor Cells

Human pancreatic neuroendocrine BON1, bronchopulmonary NCI-H727, and midgut GOT1 tumor cells were incubated with NVP-CGM097 at concentrations of 100,500 , and 2,500 $\mathrm{nM}$ for $24 \mathrm{~h}$.

In p53 $3^{\text {wild type }}$ GOT1 cells, incubation with NVPCGM097 caused a dose-dependent increase in the expression levels of $\mathrm{p} 53$ and its known downstream targets MDM2, pMDM2, p21, and PUMA (p53 upregulated modulator of apoptosis) (Fig. 2; online suppl. Fig. 2). NVP-CGM097 also caused a decrease in phospho-Rb and E2F1 (Fig. 2). Furthermore, NVP-CGM097 decreased the expression of cyclin B1 and increased the expression of cyclin D3 (Fig. 2). These findings coincide with known effects of other MDM2 inhibitors on the p53/MDM2/ PUMA/p21/pRb/E2F1 cascade [12, 45, 46]. Further p53mediated downstream effects alter the p53/MDM2/ $\mathrm{PUMA} / \mathrm{p} 21 / \mathrm{pRb} / \mathrm{E} 2 \mathrm{~F} 1$ cascade and mediate the antitumoral effects of MDM2 inhibitors [12, 35, 46].

In contrast, p53 $3^{\text {mutated }}$ cancer cells have been demonstrated to be most often insensitive to MDM2 inhibitors [35]. Accordingly, when investigated in $\mathrm{p} 53^{\text {mutated }} \mathrm{BON} 1$ and p53 $3^{\text {mutated }}$ NCI-H727 cells, NVP-CGM097 only caused an increase in pMDM2 and in MDM2 (Fig. 2). However, no significant effects were observed on the downstream targets p53, PUMA, p21, phospho-Rb, E2F1, cyclin B1, or cyclin D3 (Fig. 2). Thus, in contrast to p53 $3^{\text {wild type }}$ GOT1 cells, p53 $3^{\text {mutated }}$ BON1 and p53 ${ }^{\text {mutated }}$ NCI-H727 cells were insensitive to the MDM2 inhibitor NVP-CGM097 and its downstream effects on the p53/ MDM2/PUMA/p21/pRb/E2F1 cascade.

Herpesvirus-associated ubiquitin-specific protease (HAUSP) is a deubiquitinase which is reciprocally acting with the ubiquitinase MDM2 in regulating the MDM2p53 complex $[47,48]$ and the death domain-associated protein 6 (DAXX) [49]. Therefore, we also investigated the effect of the MDM2 inhibitor NVP-CGM097 on HAUSP and DAXX protein expression. In all 3 cell lines, incubation with NVP-CGM097 had no effect on the expression levels of HAUSP and DAXX (Fig. 2). Thus, MDM2 inhibition by NVP-CGM097 does not seem to exert any direct or indirect effects mediated by HAUSP or DAXX expression status.

The MDM2 Inhibitor NVP-CGM097 Inhibits the Cell Viability of Neuroendocrine GOT1 Tumor Cells

Human pancreatic neuroendocrine BON1, bronchopulmonary NCI-H727, and midgut GOT1 tumor cells were incubated with NVP-CGM097 at a concentration range of 4-2,500 nM for 48, 96, and $144 \mathrm{~h}$ (Fig. 3). Incubation of p53 ${ }^{\text {wild type }}$ GOT1 cells with NVP-CGM097 at 100, 500 , and 2,500 $\mathrm{nM}$ for $48 \mathrm{~h}$ caused a significant decline in cell viability to $89.2 \pm 3.8 \%(p<0.05), 89.7 \pm 8.9 \%(\mathrm{~ns})$, and $74.3 \pm 15.7 \%(p<0.05)$, respectively (Fig. 3a). Incubation of p53 ${ }^{\text {wild type }}$ GOT1 cells with NVP-CGM097 at 100, 500 , and 2,500 $\mathrm{nm}$ for $96 \mathrm{~h}$ caused a significant decline in cell viability to $84.9 \pm 9.2 \%(p<0.05), 77.4 \pm 6.6 \%(p<$ $0.01)$, and $47.7 \pm 9.2 \%(p<0.01)$, respectively (Fig. $3 b)$. Incubation of $\mathrm{p} 53^{\text {wild type }}$ GOT1 cells with NVP-CGM097 at 100,500 , and $2,500 \mathrm{nM}$ for $144 \mathrm{~h}$ caused a significant decline in cell viability to $89.9 \pm 0.7 \%(p<0.001), 76.6 \pm$ $2.9 \%(p<0.001)$, and $36.9 \pm 7.9 \%(p<0.001)$, respectively (Fig. 3c). The calculated $\mathrm{IC}_{50}$ for NVP-CGM097 in GOT1 cells during incubation for $144 \mathrm{~h}$ was $1.84 \mu \mathrm{M}$ (online suppl. Fig. 4).

In contrast, incubation of $\mathrm{p} 53^{\text {mutated }} \mathrm{BON} 1$ and p53 $3^{\text {mutated }}$ NCI-H727 cells with NVP-CGM097 caused no significant effect on cell viability (Fig. 3 ). Thus, in contrast to $\mathrm{p} 53^{\text {wild type }} \mathrm{GOT} 1$ cells, both $\mathrm{p} 53^{\text {mutated }} \mathrm{BON} 1$ and p53 $3^{\text {mutated }}$ NCI-H727 cells were insensitive to MDM2 inhibition by the MDM2 inhibitor NVP-CGM097.

The MDM2 Inhibitor NVP-CGM097 Shows Additive Antiproliferative Effects with 5-Fluorouracil, Temozolomide, or Everolimus (RAD001) on the Cell Viability of Neuroendocrine GOT1 Tumor Cells

Human midgut GOT1 tumor cells were incubated for $96 \mathrm{~h}$ with NVP-CGM097 (500 nM) alone or in combination with 5-fluorouracil ( 5 or $25 \mu \mathrm{M}$ ), temozolomide (50 $\mu \mathrm{M}$ ), or everolimus (RAD001; $10 \mathrm{nM}$ ) (Fig. 4a). Incubation with the single compounds NVP-CGM097 (500 nM), 5-fluorouracil (5 or $25 \mu \mathrm{M})$, temozolomide $(50 \mu \mathrm{M})$, or everolimus (RAD001; $10 \mathrm{nM}$ ) caused inhibition of cell viability to $79.0 \pm 2.5 \%(p<0.01), 86.0 \pm 4.2 \%(p<0.05)$, $65.5 \pm 6.2 \%(p<0.05), 88.3 \pm 4.0 \%(p<0.05)$, and $77.9 \pm$ $7.7 \%(p<0.05)$, respectively, versus the control (Fig. 4a). Co-incubation of NVP-CGM097 with 5-fluorouracil (5 or $25 \mu \mathrm{M}$ ), temozolomide $(50 \mu \mathrm{M}$ ), or everolimus (RAD001; $10 \mathrm{nM}$ ) caused additive effects, with inhibition
6

Neuroendocrinology 2018;106:1-19 DOI: $10.1159 / 000453369$
Reuther et al. 
Fig. 3. Cell viability assay of $\mathrm{p} 53^{\text {wild type }}$ GOT1, p53 $3^{\text {mutated }}$ BON1, and p53 $3^{\text {mutated }}$ NCI-H727 cells during incubation with the MDM2 inhibitor NVP-CGM097 for 48 (a), 96 (b), and $144 \mathrm{~h} \mathrm{(c).} \mathrm{Shown} \mathrm{are} \mathrm{the} \mathrm{arith-}$ metic means and standard deviations of 4 independent experiments. Statistical analysis with the $t$ test showed significant results $\left({ }^{*} p<0.05,{ }^{* *} p<0.01,{ }^{* * *} p<0.001\right)$.
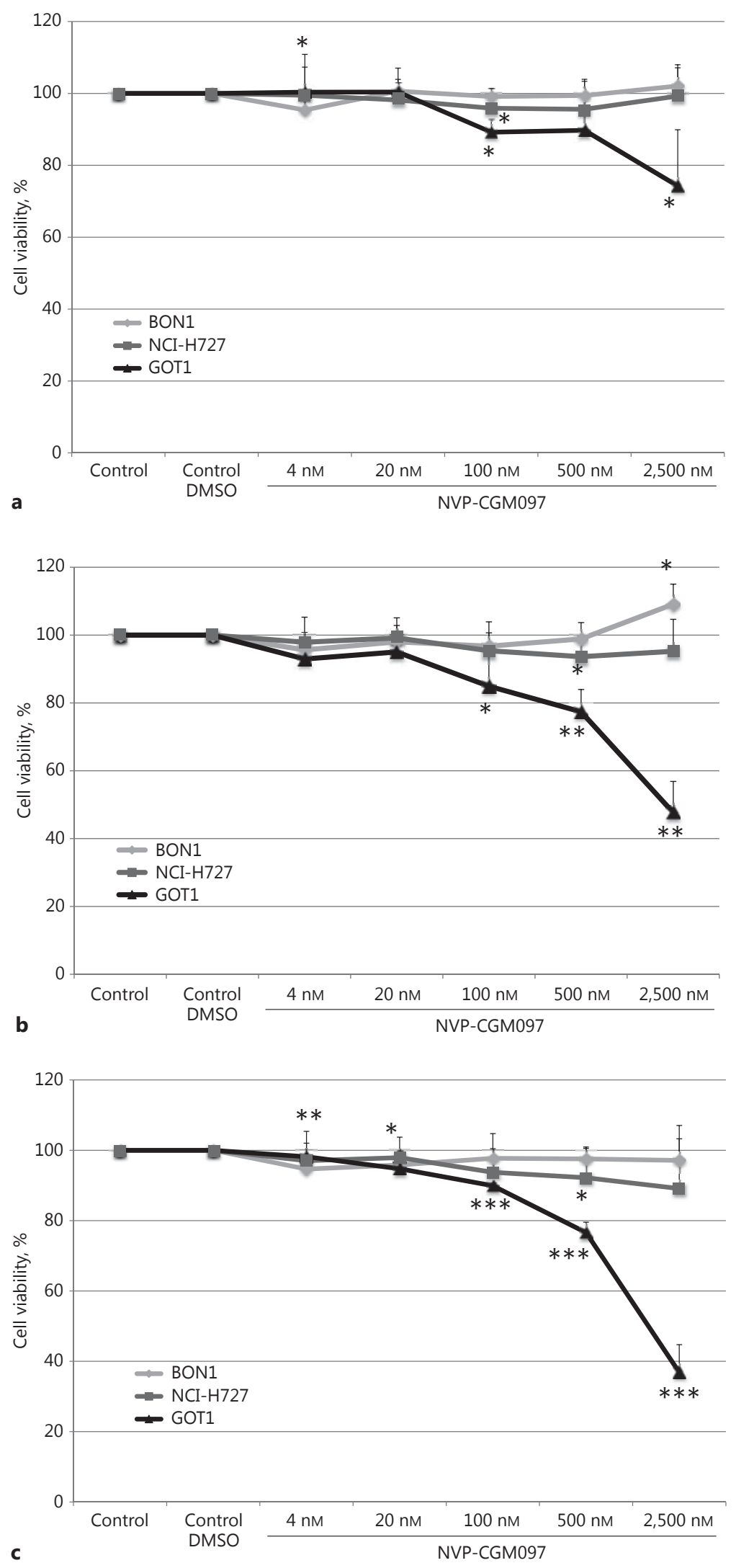
Proliferation in NET Cell Line GOT1
Neuroendocrinology 2018;106:1-19 DOI: $10.1159 / 000453369$ 


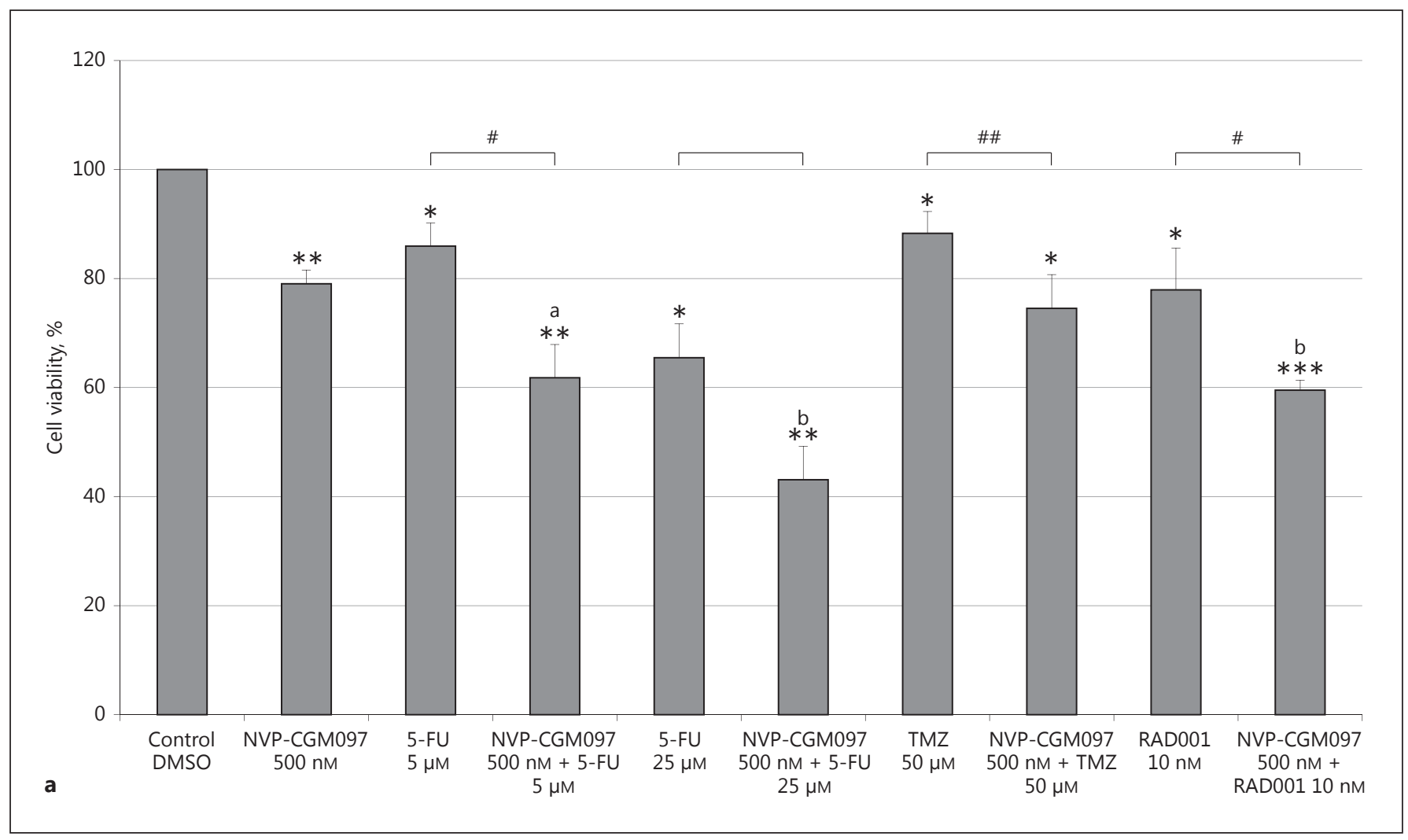

Fig. 4. Cell viability assay of $\mathrm{p} 53^{\text {wild type }} \mathrm{GOT} 1$ (a), p53 $3^{\text {mutated }}$ NCI-H727 (b), and p53 $3^{\text {mutated }}$ BON1 (c) cells during incubation for 96 h with the MDM2 inhibitor NVP-CGM097 alone and in combination with 5-fluorouracil (5-FU), temozolomide (TMZ), or everolimus (RAD001). Shown are the arithmetic means and standard deviations of 3 independent experiments. Statistical analysis with the $t$ test showed significant results against the untreated control $\left(* p<0.05,{ }^{* *} p<0.01,{ }^{* * *} p<0.001\right)$, against the NVP-CGM097 control ( ${ }^{a} p<$ $0.05,{ }^{\mathrm{b}} p<0.01,{ }^{\mathrm{c}} p<0.001$ ), and of 5-fluorouracil, temozolomide, or everolimus (RAD001) alone versus NVP-CGM097 plus 5-fluorouracil, temozolomide, or everolimus (RAD001) ( $\left.{ }^{\#} p<0.05,{ }^{\# \#} p<0.01\right)$.

(For rest of figure see next page.)

of cell viability to $61.8 \pm 6.1 \%(p<0.05), 43.1 \pm 6.1 \%(p<$ $0.01), 74.5 \pm 6.2 \%(\mathrm{~ns})$, and $59.5 \pm 1.8 \%(p<0.01)$, respectively, versus NVP-CGM097 alone (Fig. 4a).

Human bronchial NCI-H727 and pancreatic BON1 tumor cells were incubated for $96 \mathrm{~h}$ with NVP-CGM097 (500 nM) alone or in combination with 5-fluorouracil (1 or $5 \mu \mathrm{M}$ ), temozolomide (BON1: $50 \mu \mathrm{M}$; NCI-H727: 500 $\mu \mathrm{M})$, or everolimus (RAD001; $10 \mathrm{nM}$ ) (Fig. 4b, c). The proliferation of NCI-H727 and BON1 cells was significantly inhibited by 5 -fluorouracil $(1 \mu \mathrm{M})$ to $80.0 \pm 6.0 \%$ ( $p$ $<0.05)$ and $64.6 \pm 9.9 \%(p<0.05)$, by 5 -fluorouracil ( 5 $\mu \mathrm{M})$ to $48.9 \pm 6.9 \%(p<0.01)$ and $36.8 \pm 3.9 \%(p<0.01)$, by temozolomide (BON1: $50 \mu \mathrm{M}$; NCI-H727: $500 \mu \mathrm{M})$ to $79.8 \pm 11.6 \%$ (ns) and $88.9 \pm 6.5 \%$ (ns), and by everolimus (RAD001; $10 \mathrm{nM})$ to $64.1 \pm 5.4 \%(p<0.01)$ and 48.2 $\pm 6.1 \%(p<0.01)$, respectively. Despite the lack of a significant effect of NVP-CGM097 alone on tumor cell pro- liferation of NCI-H727 and BON1 cells (Fig. 3b, c), we also investigated NVP-CGM097 in co-incubation experiments in order to test for a possible effect as a sensitizer to 5-fluorouracil, temozolomide, or everolimus. However, also in these co-incubation experiments, NVPCGM097 caused no significant effect on NCI-H727 and BON1 cell viability (Fig. 4 b, c). Thus, in contrast to p53 $3^{\text {wild }}$ type GOT1 cells, both p53 $3^{\text {mutated }}$ BON1 and p53 $3^{\text {mutated }} \mathrm{NCI}-\mathrm{H} 727$ cells were insensitive to MDM2 inhibition alone as well as in co-incubation experiments.

\section{The MDM2 Inhibitor NVP-CGM097 Shows Additive} Effects with 5-Fluorouracil on the Expression Profile of p53, p21, PUMA, phospho-Rb, and E2F1 in p53 wild type GOT1 Tumor Cells

5-Fluorouracil has been reported to inhibit MDM2 through ribosomal proteins and thus to activate p53 ex- 


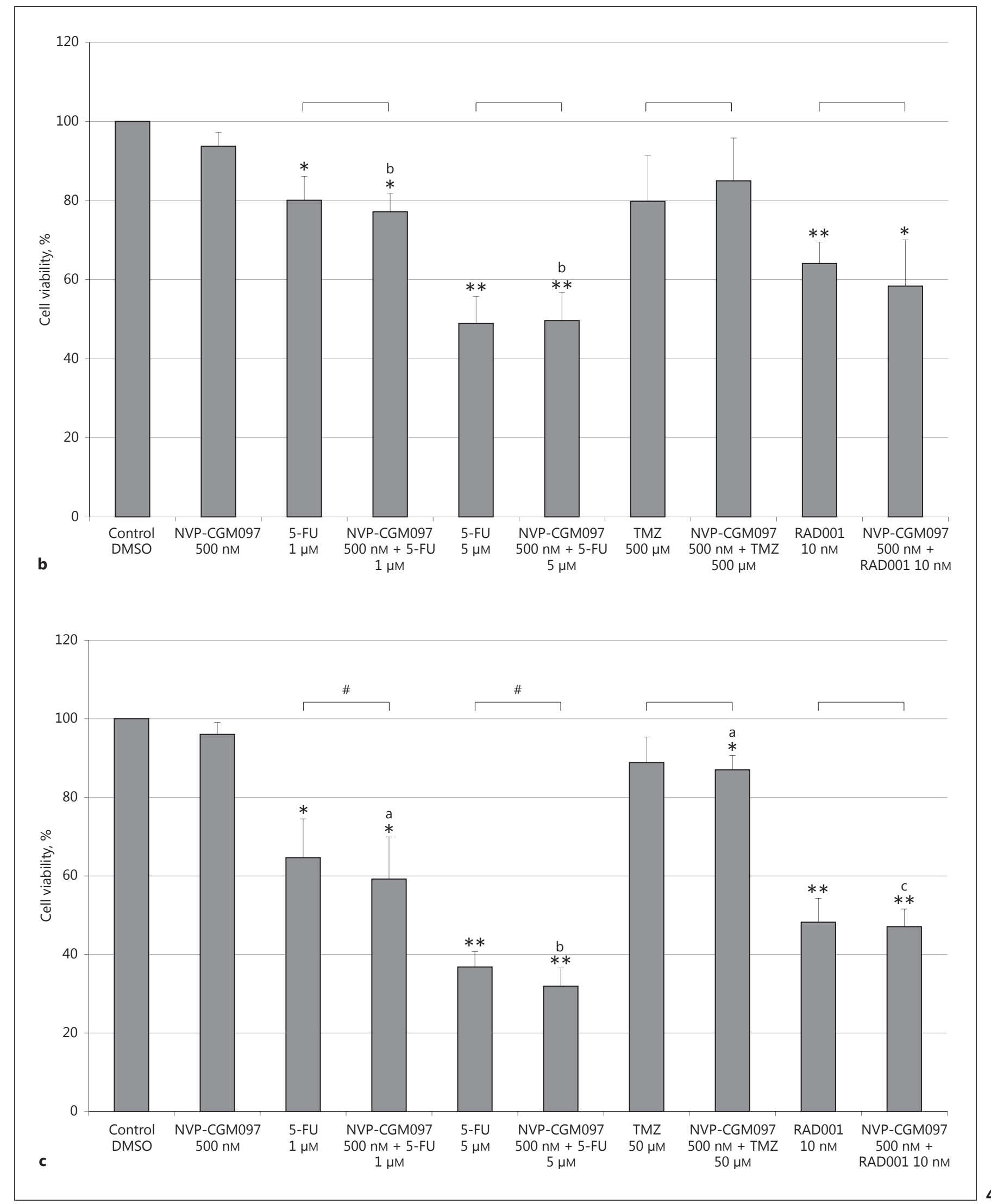


pression in cancer cells [50]. Therefore, we investigated whether there are additive effects of co-incubation with 5-fluorouracil and the MDM2 inhibitor NVP-CGM097 on the expression profile of p53, p21, PUMA, phospho$\mathrm{Rb}$, and E2F1. A Western blot analysis of $\mathrm{p} 53^{\text {wild type }} \mathrm{GOT} 1$ cells demonstrated an increase in p53, p21, and PUMA expression levels during incubation with 5 -fluorouracil alone (Fig. 5). Co-incubation of GOT1 cells with NVPCGM097 (500 nM) and 5-fluorouracil $(50 \mu \mathrm{M})$ caused synergistic effects, increasing the expression levels of pMDM2, MDM2, p53, p21, and PUMA as well as decreasing the expression levels of phospho-Rb and E2F1, respectively (Fig. 5). Thus, the additive effects of 5-fluorouracil and NVP-CGM097 on GOT1 cell proliferation are mediated by additive effects on the MDM2-p53PUMA-p21-Rb-E2F1 axis.

\section{The MDM2 Inhibitor NVP-CGM097 Shows}

Additive Effects with Temozolomide on

Increasing the Expression of $p 53$ in p53 wild type

GOT1 Tumor Cells

In p53 $3^{\text {wild type }}$ GOT1 cells, NVP-CGM097 and temozolomide showed an additive effect on inhibition of cell viability (Fig. 4a). Therefore, we investigated whether there were additive effects of co-incubation with temozolomide and the MDM2 inhibitor NVP-CGM097 on the expression profile of $\mathrm{p} 53, \mathrm{p} 21$, PUMA, phospho-Rb, and E2F1. Co-incubation of NVP-CGM097 and temozolomide in GOT1 cells caused additive effects on increasing the expression of p53 (Fig. 5). Thus, the additive effects of temozolomide and NVP-CGM097 on GOT1 cell proliferation might be mediated by additive effects on p53 expression. However, we observed no further additive downstream effects of NVP-CGM097 and temozolomide on the MDM2-p53-PUMA-p21-RbE2F1 axis (Fig. 5).

Low MGMT expression in NETs is associated with higher sensitivity to temozolomide [51, 52]. In human glioblastoma cells, the MDM2 inhibitor ISA27 and temozolomide have been reported to exert synergistic antiproliferative effects [53], while expression of p53 wild type downregulates MGMT expression in glioblastoma [54-57] and sensitizes glioblastoma cells to temozolomide [58]. Therefore, we aimed to investigate whether there are additive effects of co-incubation with temozolomide and the MDM2 inhibitor NVP-CGM097 on the expression profile of MGMT. However, all of the 3 neuroendocrine cell lines tested demonstrated no detectable MGMT expression under basal conditions (Fig. 1).

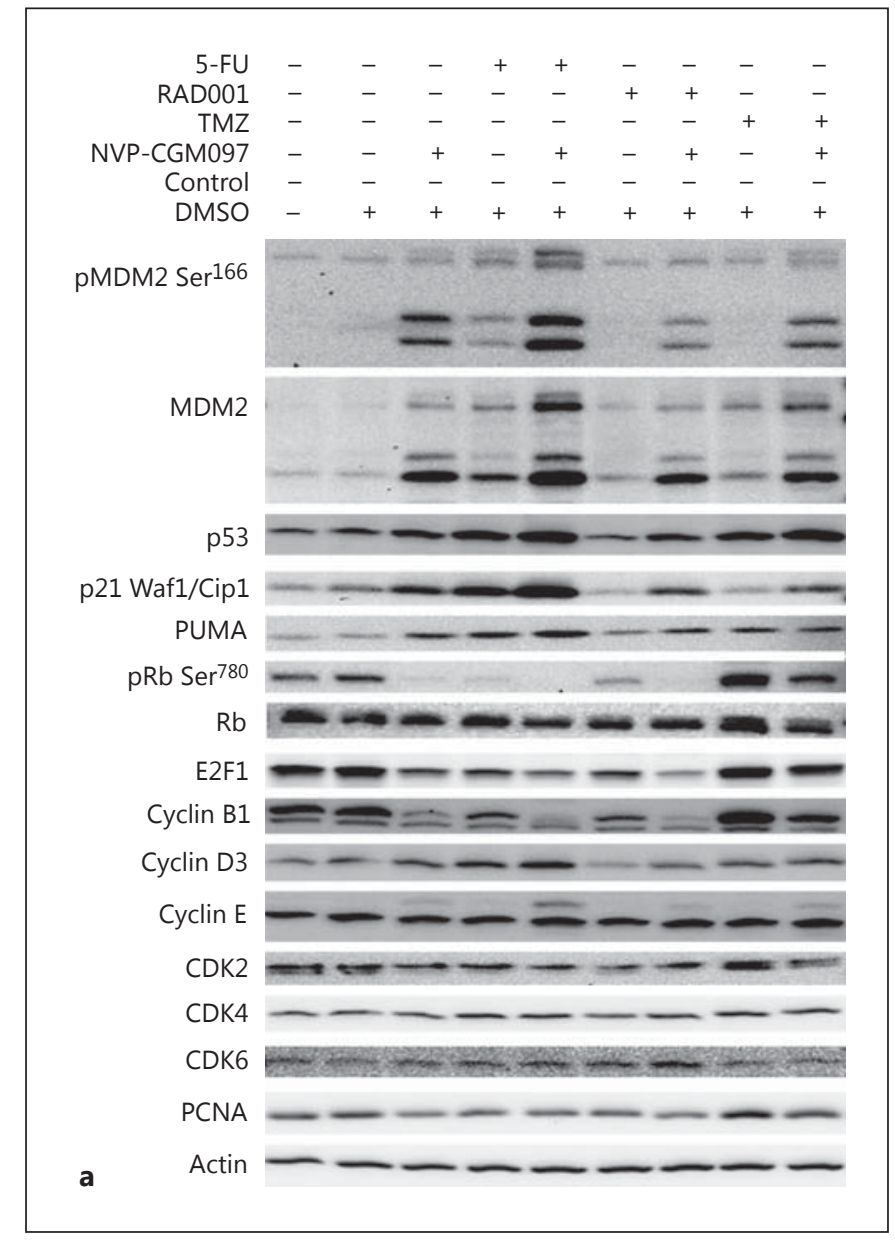

Fig. 5. Western blot analysis of pMDM2, MDM2, p53, p21, PUMA, pRb, Rb, E2F1, cyclin B1, cyclin D3, cyclin E, CDK2, CDK4, CDK6, PCNA, and actin in p53 ${ }^{\text {wild type }}$ GOT1 cells during 48-h incubation with the MDM2 inhibitor NVP-CGM097 alone and in combination with 5-fluorouracil (5-FU), temozolomide (TMZ), and everolimus (RAD001). a Representative blot out of 3 independently performed experiments.

The MDM2 Inhibitor NVP-CGM097 Shows

Additive Effects with Everolimus (RAD001) on

Decreasing phospho-Rb Expression in $p 53^{\text {wild type }}$

GOT1 Tumor Cells

In different carcinoma cell lines, the mTOR inhibitor rapamycin has been reported to inhibit MDM2 expression and to stimulate p53-dependent apoptosis $[59,60]$. However, also controversial findings with mTOR inhibition blunting the p53 response to nucleolar stress have been reported $[61,62]$. Rapamycin has recently been shown to inhibit the $\mathrm{Rb}$ pathway [63]. Therefore, we investigated whether there are additive effects of co-incubation with everolimus (RAD001) and the MDM2 inhibitor
10

Neuroendocrinology 2018;106:1-19 DOI: $10.1159 / 000453369$
Reuther et al. 
Fig. 5. Western blot analysis of pMDM2, MDM2, p53, p21, PUMA, pRb, Rb, E2F1, cyclin B1, cyclin D3, cyclin E, CDK2, CDK4, CDK6, PCNA, and actin in p53 $3^{\text {wild type }}$ GOT1 cells during 48-h incubation with the MDM2 inhibitor NVPCGM097 alone and in combination with 5-fluorouracil (5-FU), temozolomide (TMZ), and everolimus (RAD001). b Quantification of the Western blot data for $\mathrm{pMDM} 2, \mathrm{MDM} 2, \mathrm{pRb}, \mathrm{Rb}, \mathrm{p} 21$, and p53. Shown are the arithmetic means and standard deviations of 3 independent experiments. Statistical analysis with the $t$ test showed significant results against untreated the control $\left(^{*} p<0.05\right.$, ** $p<0.01$, $* * * p<0.001)$, against the NVP-CGM097 control ( $\left.{ }^{\mathrm{a}} p<0.05,{ }^{\mathrm{b}} p<0.01\right)$, and of 5 -fluorouracil, temozolomide, or everolimus (RAD001) alone versus NVP-CGM097 plus 5-fluorouracil, temozolomide, or everolimus (RAD001) $\left(^{\#} p<0.05\right.$, \#\# $p<$ $0.01)$.

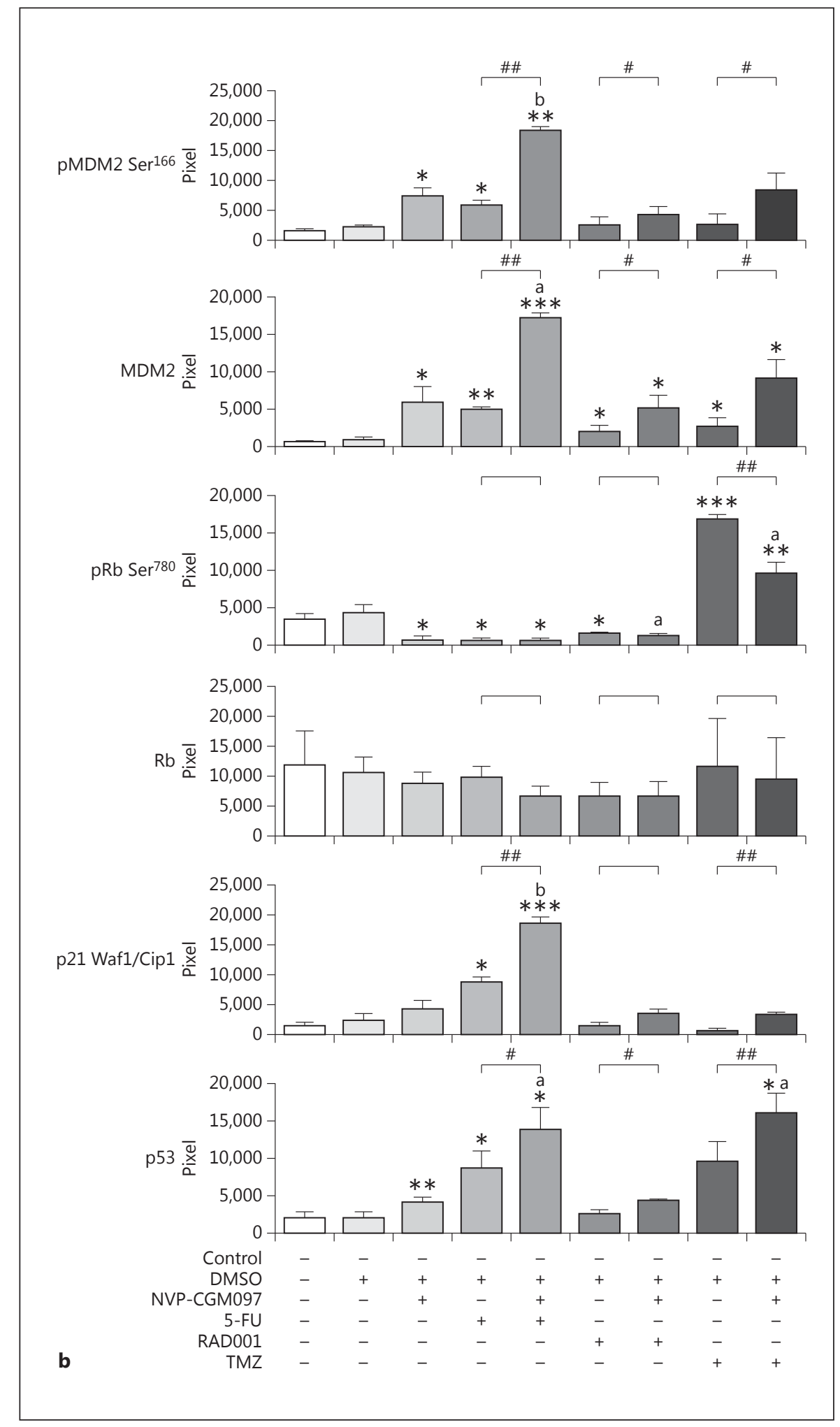

Neuroendocrinology 2018;106:1-19 


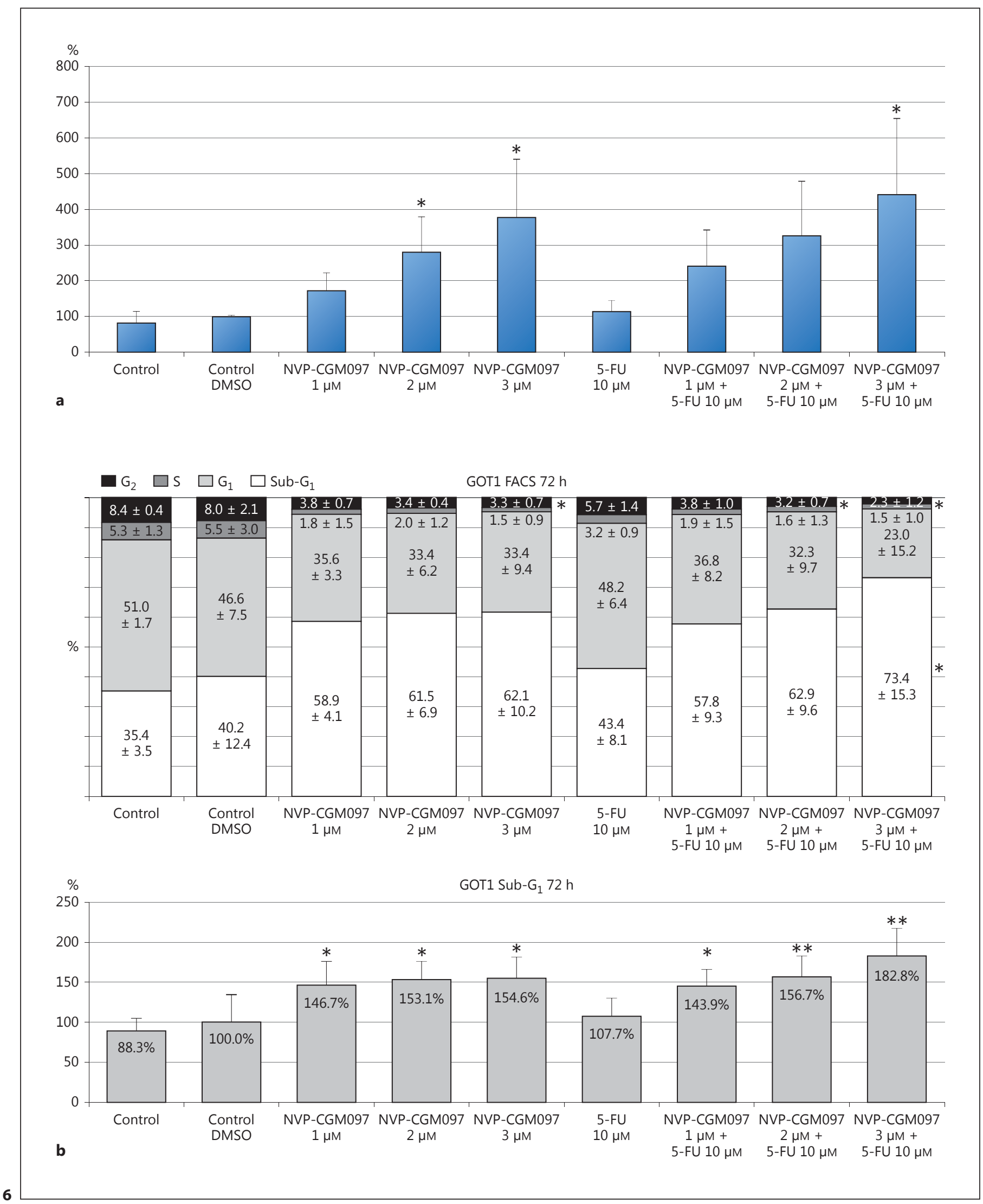

(For rest of figure and legend see next page.) 
NVP-CGM097 on the expression profiles of p53, p21, PUMA, phospho-Rb, and E2F1. Co-incubation of NVPCGM097 and everolimus (RAD001) in GOT1 cells caused additive effects on decreasing the expression of phospho$\mathrm{Rb}$ (Fig. 5). Thus, the additive effects of everolimus (RAD001) and NVP-CGM097 on GOT1 cell proliferation might be mediated by additive inhibitory effects on phospho-Rb expression, thereby inhibiting the Rb pathway. However, we observed no further additive downstream effects of NVP-CGM097 and temozolomide on the MDM2-p53-PUMA-p21-Rb-E2F1 axis (Fig. 5).

\section{The MDM2 Inhibitor NVP-CGM097 Causes an}

Increase in Caspase 3/7 Activity and in Sub-G Events, and It Affects the Cell Cycle Checkpoints Chk1 and CDK1, Cyclin B1, and Cyclin D3 in p53 $3^{\text {wild type }}$ GOT1

\section{Tumor Cells}

Incubation of GOT1 cells with NVP-CGM097 for 72 $\mathrm{h}$ caused a severalfold increase in caspase $3 / 7$ activity (Fig. 6a) and in sub- $\mathrm{G}_{1}$ events (Fig. 6b), although no PARP cleavage was detected (Fig. 6c). Incubation of GOT1 cells with NVP-CGM097 for $72 \mathrm{~h}$ caused a decrease in Chk1, CDK1 (cdc2), and cyclin B1 as well as an

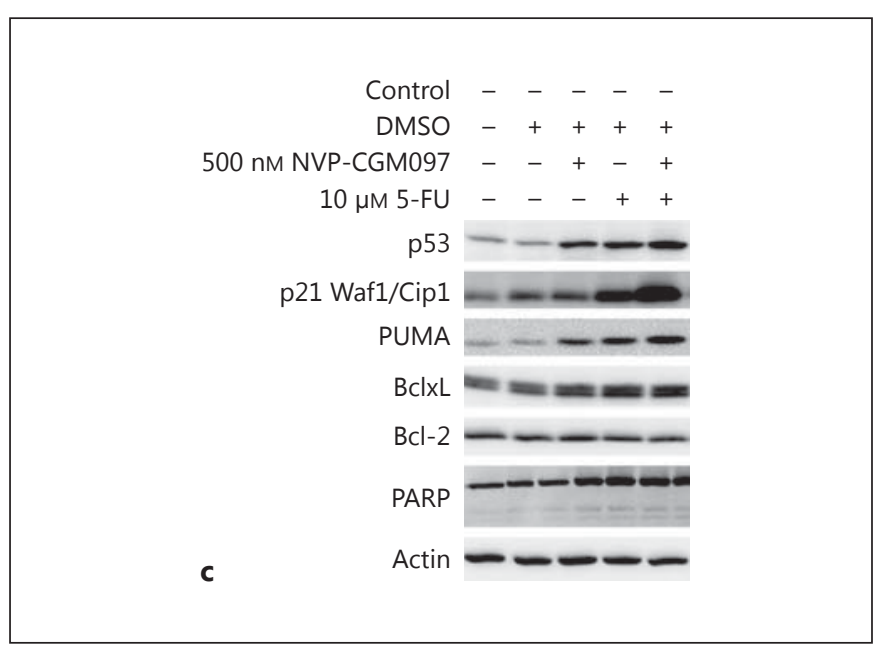

Fig. 6. Caspase $3 / 7$ assay (a) and cell cycle analysis by FACS (b) in p53 ${ }^{\text {wild type }}$ GOT1 cells during 72-h incubation with the MDM2 inhibitor NVP-CGM097 alone and in combination with 5-fluorouracil (5-FU). Shown are the arithmetic means and standard deviations of 3 independent experiments. Statistical analysis with the $t$ test showed significant results against the untreated control $*^{*} p$ $\left.<0.05,{ }^{* *} p<0.01\right)$. c Western blot analysis of apoptosis-related proteins in $\mathrm{p} 53^{\text {wild type }}$ GOT1 cells during 48-h incubation with the MDM2 inhibitor NVP-CGM097 alone and in combination with 5-fluorouracil. A representative blot out of 3 independently performed experiments is shown.

NVP-CGM097 Inhibits Tumor Cell

Proliferation in NET Cell Line GOT1 increase in cyclin D3 (Fig. 7). Thus, these data suggest that induction of apoptosis and alteration of cell cycle control both contribute to the antiproliferative effects of NVP-CGM097.

\section{Octreotide Does Not Affect the Proliferation of} p53 $3^{\text {wild type }}$ GOT1 Tumor Cells in vitro

Antitumoral effects of the somatostatin analogs octreotide and lanreotide in patients with NETs have been proven in clinical phase III studies [64-67] and are well established in clinical treatment guidelines [68]. We previously demonstrated that GOT1 cells express somatostatin receptor subtype 2 mRNA [69], and GOT1 cell tumors in murine xenografts are a well-established model for somatostatin receptor-mediated peptide receptor radiotherapy with $\left[{ }^{177} \mathrm{Lu}-\mathrm{DOTA}{ }^{0}, \mathrm{Tyr}^{3}\right]$ octreotate or $\left[{ }^{177} \mathrm{Lu}-\right.$ DOTA $^{0}, \mathrm{Tyr}^{3}$ ] octreotide [70-73]. Therefore, we aimed to investigate the effects of octreotide in GOT1 cells in vitro alone and in combination with NVP-CGM097.

However, in vitro incubation of GOT1 cells with octreotide $(0.1-10.0 \mu \mathrm{M})$ for $144 \mathrm{~h}$ and $216 \mathrm{~h}$ did not significantly alter cell proliferation (online suppl. Fig. 5A, B). Also Western blot analysis of GOT1 cells revealed no rapid (online suppl. Fig. 6) or late-onset (Fig. 7) effects of octreotide on the investigated parameters p53, p21, pRb, Rb, pAkt, Akt, pErk1/2, Erk1/2, Chk1, CDK1 (cdc2), cyclin B1, and cyclin D3. Thus, in our experimental setup, GOT1 cells seemed not to be responsive to octreotide and thus not to be an appropriate in vitro model for studying direct effects of octreotide.

\section{Discussion and Conclusion}

The E3 ubiquitin ligase MDM2 associates with the tumor suppressor p53 and causes inactivation of p53 by ubiquitin-dependent protein degradation of the MDM2p53 protein complex [11]. MDM2 inhibitors inhibit protein interaction of MDM2 with p53 and subsequent degradation of $\mathrm{p} 53$ via the proteasome ubiquitin pathway, thus increasing the $\mathrm{p} 53^{\text {wild type }}$ expression level of the cancer cell. Inhibition of MDM2 by small molecules, and thus reactivation of p53 expression, seems a promising novel target in oncology [11-14]. Several small molecule MDM2 inhibitors including NVP-CGM097 (NCT01760525, Novartis) have entered clinical phase I trials (online suppl. Table. 1) [11-15].

The small molecule inhibitor NVP-CGM097 is a novel MDM2 inhibitor [15-17] which binds to human MDM2 with a $K_{\mathrm{i}}$ value of $1.3 \mathrm{nM}$ [15]. We investigated the

Neuroendocrinology 2018;106:1-19 13 


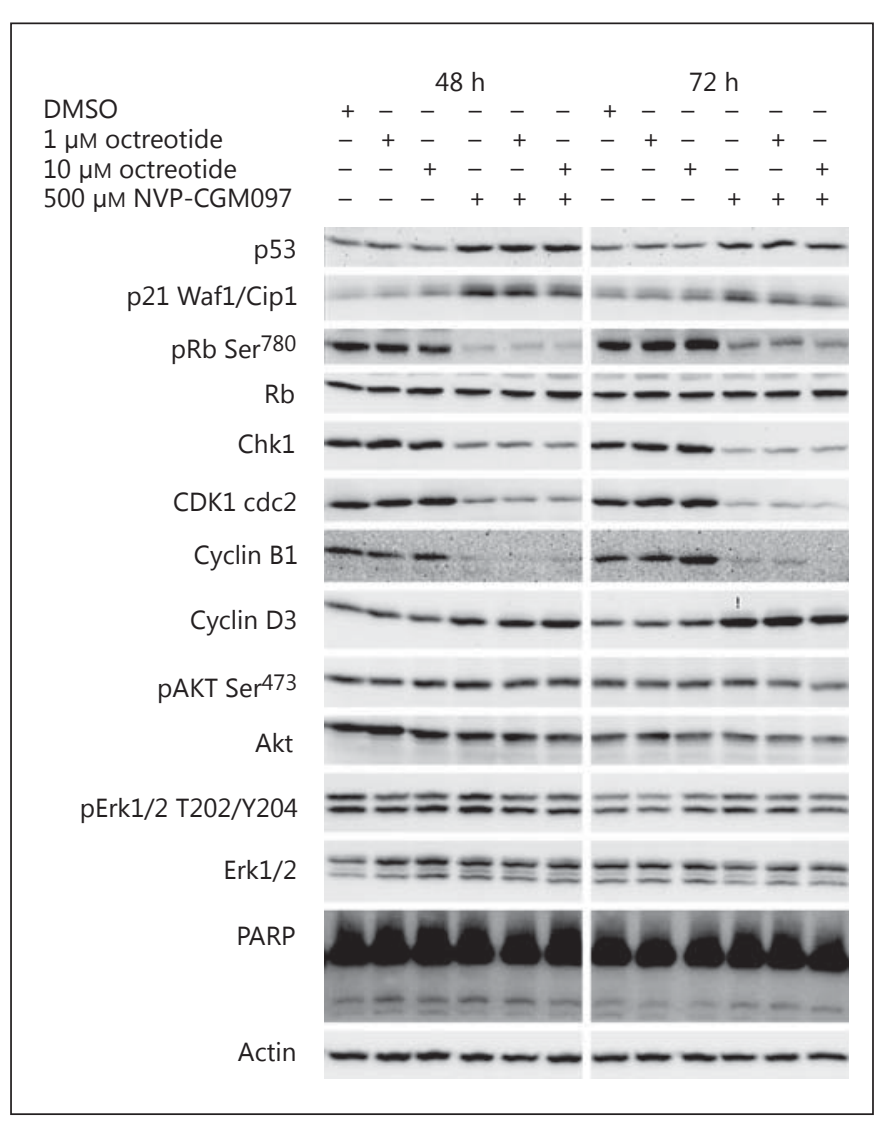

Fig. 7. Western blot analysis of p53, p21, pRb, Rb, Chk1, CDK1 (cdc2), cyclin B1, cyclin D3, pAkt, Akt, pErk1/2, Erk1/2, PARP, and actin in $\mathrm{p} 53^{\text {wild type }}$ GOT1 cells during 48- and 72-h incubation with the MDM2 inhibitor NVP-CGM097 alone and in combination with octreotide. A representative blot out of 3 independently performed experiments is shown.

in vitro effects of the MDM2 inhibitor NVP-CGM097 on human NET cells of small intestinal (GOT1), pancreatic (BON1), and bronchial (NCI-H727) origin. We demonstrated for the first time that MDM2 inhibition by NVPCGM097 is antiproliferative in p53 ${ }^{\text {wild type }}$ GOT1 tumor cells and shows additive effects with 5-fluorouracil, temozolomide, or everolimus (RAD001) in this preclinical NET model. The calculated IC $_{50}$ of NVP-CGM097 in GOT1 cells during incubation for $144 \mathrm{~h}$ was $1.84 \mu \mathrm{M}$. Jeay et al. [15] investigated the $\mathrm{IC}_{50}$ of the $2 \mathrm{MDM} 2$ inhibitors CFC218 and CGM097 in 113 p53 $3^{\text {wild type }}$ cell lines and 243 p53 ${ }^{\text {mutated }}$ cell lines and reported for the most sensitive p53 $3^{\text {wild type }}$ cell lines an $\mathrm{IC}_{50}$ between 1 and $4 \mu \mathrm{M}$. Thus, the GOT1 cells used in our model are sensitive to MDM2 inhibition by NVP-CGM097.

In contrast, $\mathrm{p} 53^{\text {mutated }} \mathrm{BON} 1$ and $\mathrm{p} 53^{\text {mutated }} \mathrm{NCI}-\mathrm{H} 727$ tumor cells were insensitive to NVP-CGM097. The fact that the MDM2 inhibitor NVP-CGM097 is only effective in p53 $3^{\text {wild type }}$ cells was demonstrated before by Jeay et al. [15]. Another human NET cell line, KRJ-1, has also been reported to harbor a nonmutated TP53 gene and to be sensitive to treatment with the MDM2 inhibitor nutlin-3 $[18,19]$. Thus, the human NET cell lines GOT1 and KRJ1 expressing $\mathrm{p} 53^{\text {wild type }}$ seem valid models for the future evaluation of $\mathrm{p} 53$-mediated treatment strategies in NETs.

Expression of $\mathrm{p} 53^{\text {wild type }}$ in cancers is essential for their sensitivity to MDM2 inhibitors, as has been demonstrated in many different cancer cell lines in vitro $[35,74]$. Accordingly, also our own data on p53 $3^{\text {wild type }}$ GOT1 cells, as well as preliminary data from other researchers on p53 $3^{\text {wild type }}$ KRJ-1 cells $[18,19]$, indicate that p53 $3^{\text {wild type }}$ expression is essential for the sensitivity of NET cells to MDM2 inhibition. In a sequence analysis of exons 4-10 of TP53, only GOT1 cells showed no mutations in the TP53 gene. In contrast, BON1 cells exhibited a stop-gain mutation (p.R342Stop; c.1024 C>T) in exon 10 of the TP53 gene (online suppl. Fig. 1A). This mutation has previously been reported in 92 tumor tissues, 13 times as a germ line mutation, and in 9 cell lines (IARC TP53 Database, version R17, November 2013). In a recent paper, this mutation was confirmed by Vandamme et al. [75], who reported whole genome sequencing data on pancreatic neuroendocrine BON1 and QGP-1 cells. BON1 cells most probably express a truncated $50-\mathrm{kDa}$ p53 protein (Fig. 1), due to the stop-gain mutation p.R342Stop (c.1024 $\mathrm{C}>\mathrm{T}$ ) in exon 10 of the TP53 gene (online suppl. Fig. 1A). However, expression of a truncated splice variant of p53 could be an alternative explanation, as various p 53 splice variants are known in the literature [76, 77]. This could be revealed by future experiments with $\mathrm{N}$-terminal- and C-terminal p53 antibodies.

NCI-H727 cells exhibit an insertion of 9 bp in exon 5 of TP53 (online suppl. Fig. 1B), leading to an insertion of 3 amino acids in the open reading frame (online suppl. Fig. 1C). This mutation is listed in the IARC TP53 Database (ATCC Identification No. CRL-5815).

Only p53 $3^{\text {wild type }}$ GOT1 cells were a valid model for investigating the effects of the MDM2 inhibitor NVPCGM097 alone and in combination with other agents in vitro (Fig. 2, 4). The BON1 and NCI-H727 cell lines harbor mutations in the TP53 gene, indicating expression of a functionally inactive $\mathrm{p} 53^{\text {mutated }}$ protein. Accordingly, the MDM2 inhibitor NVP-CGM097 showed no antitumoral effects in $\mathrm{p} 53^{\text {mutated }} \mathrm{BON} 1$ and $\mathrm{p} 53^{\text {mutated }} \mathrm{NCI}-$ H727 cells (Fig. 2, 4). These findings indicate that NVPCGM097 exerts its antitumoral effects by a highly specific impact on the MDM2-p53 $3^{\text {wild type }}$ complex.
14

Neuroendocrinology 2018;106:1-19 DOI: $10.1159 / 000453369$
Reuther et al. 
NETs of small intestinal and pancreatic origin have been shown to exhibit only a low $(<5 \%)$ frequency of somatic TP53 gene mutations $[21,22]$. On the other hand, NETs harbor copy number gains in the endogenous p53 inhibitors MDM2 in 20\%, MDM4 in 30\%, and WIP1 in $51 \%$ of the cases [20]. Thus, inhibiting MDM2 and increasing the expression of $\mathrm{p} 53^{\text {wild type }}$ in these tumors might be a promising target for patients with NETs [18, 19] and should be evaluated in further preclinical studies and clinical trials.

Whole exome sequencing of various human NET cell lines including pancreatic BON1 and QGP-1 cells $[78,79]$ as well as bronchial NCI-H727 cells [78] demonstrated that the mutation rates and patterns of the tested NET cell lines were distinct from well-differentiated NETs in patients. Thus, the available human NET cell lines might not adequately reflect the tumor biology of well-differentiated NETs. This is a major limitation of our study, as we could identify only 1 valid cell line model with $\mathrm{p} 53^{\text {wild type }}$ expression. This is in contrast to the situation in vivo, as TP53 mutations are a rare event in well-differentiated NETs $[21,22]$.

Western blot analyses of GOT1 cells demonstrated that the MDM2 inhibitor NVP-CGM097 increased the expression of p53, PUMA, and p21 and decreased the expression of phospho-Rb and E2F1 in GOT1 cells (Fig. 3, 5). In contrast, NVP-CGM097 showed no significant effects on pAkt/Akt, pmTOR/mTOR, p4EBP1/4EBP1, pErk1/2/Erk1/2, pAMPK/AMPK, or pCREB/CREB (online suppl. Fig. 2, 3). These findings indicate that NVPCGM097 is a highly specific MDM2 inhibitor increasing p53, PUMA, and p21 expression and interacting with the MDM2/p53/PUMA/p21/Rb/E2F1 cascade [46]. CDK4/6cyclin D- or CDK2-cyclin E-mediated phosphorylation of $\mathrm{Rb}$ protein results in its inactivation, dissociation of the $\mathrm{pRb} / \mathrm{E} 2 \mathrm{~F}$ complex, and repression of E2F transcription factors [46, 80]. Double knockout experiments in Men1+/- Cdk4-/- mice indicate that CDK4 is essential for NET development [81]. CDK4, cyclin D1, and phospho- $\mathrm{Rb}$ are overexpressed in the majority of NETs [82]. In a xenograft model with human pancreatic neuroendocrine QGP-1 cells, the CDK4/6 inhibitor PD0332991 inhibited tumor growth [82]. Thus, reactivation of the retinoblastoma protein in NETs - either by CDK4/6 inhibitors or by MDM2 inhibitors altering the MDM2/p53/ p21/Rb cascade - seems a promising antitumor strategy.

The seemingly paradoxical increment in MDM2 and pMDM2 expression following the administration of the MDM2 inhibitor NVP-CGM097 is explained by the p53MDM2 autoregulatory feedback loop, as reported by oth-

NVP-CGM097 Inhibits Tumor Cell

Proliferation in NET Cell Line GOT1 ers [15, 83-87]. MDM2 inhibitors such as nutlin-3a [14] or NVP-CGM097 [86] act by preventing p53 binding to MDM2 and thus MDM2-targeted proteasomal degradation of p53 [14]. NVP-CGM097 thus promotes the stabilization and activation of $\mathrm{p} 53^{\text {wild type }}[15,86,87]$, causing an increased expression of various p53 target genes [86], including MDM2 itself $[15,86,87]$. The MDM2 gene contains a p53 DNA-binding site [84], and the p53MDM2 autoregulatory feedback loop encompasses p53mediated upregulation of MDM2 gene transcription as well as MDM2-mediated downregulation of p53 expression and activity by targeting $\mathrm{p} 53$ to proteasomal downregulation [83-85]. The p53-MDM2 autoregulatory feedback loop [83-85] explains the seemingly paradoxical increment in MDM2 and PMDM2 expression following the administration of the MDM2 inhibitor NVP-CGM097. MDM2 is known to be extensively phosphorylated at multiple sites [88]. Akt-mediated phosphorylation of MDM2 at Ser ${ }^{166}$ and Ser ${ }^{186}$ has been shown to increase nuclear translocation of MDM2 as well as MDM2-mediated degradation of $\mathrm{p} 53[89,90]$. As a consequence of the increased levels of MDM2 following NVP-CGM097 treatment, phosphorylation of MDM2 on Ser ${ }^{166}$ is expected to increase as well (as part of the known regulation of the p53-MDM2 pathway) and is in line with previous observations in NVP-CGM097-treated SJSA-1 MDM2amplified cells (data not published).

HAUSP is a critical regulator of the MDM2-p53 complex. MDM2 and p53 are substrates of HAUSP-mediated deubiquitination, and thus HAUSP stabilizes MDM2 and p53 $[47,48]$. Also DAXX protein expression has been reported to be regulated by the ubiquitinase MDM2 and the deubiquitinase HAUSP, reciprocally [49], while DAXX itself also regulates MDM2 [91]. Furthermore, DAXX is critically involved in telomerase regulation and telomere lengthening $[92,93]$. Mutations in the gene of the DAXX protein are frequent in pancreatic NETs [22], and loss of DAXX protein expression is a negative prognostic indicator in patients with NETs [94]. p53-mediated gene expression has recently been shown to be independent of DAXX [95]. Therefore, we also investigated the effect of the MDM2 inhibitor NVP-CGM097 on HAUSP and DAXX protein expression. In all 3 cell lines, incubation with NVP-CGM097 had no effect on the expression levels of HAUSP or DAXX (Fig. 2).

In a library of 1,169 different compounds, in vitro screening for synergistic effects with various MDM2 inhibitors found inhibitors of the PI3K/Akt/mTOR and of the MEK/MAPK pathways, as well as BCR-ABL kinase antagonists and histone deacetylase inhibitors, to cause

Neuroendocrinology 2018;106:1-19 DOI: $10.1159 / 000453369$ 
antitumoral effects in synergy with MDM2 inhibitors [35]. Another preclinical study reported synergistic antitumoral effects of the MDM2 inhibitor AMG 232 together with the cytotoxic compounds cisplatin, carboplatin, doxorubicin, or irinotecan [74]. Co-incubation of AMG 232 with these DNA-damaging, cytotoxic agents caused a synergistic increase in $\mathrm{p} 21$ expression [74].

Co-incubation of p53 $3^{\text {wild type }}$ GOT1 cells with NVPCGM097 and 5-fluorouracil caused a significantly enhanced antitumoral effect and reduced cell viability (Fig. 4a). 5-Fluorouracil was reported to increase p53 expression by affecting MDM2-p53 interaction [50]. Accordingly, in p53 $3^{\text {wild type }}$ GOT1 cells, NVP-CGM097 and 5 -fluorouracil had additive effects and increased the expression of p53, PUMA, and p21 and decreased the expression levels of phospho-Rb and E2F1 (Fig. 5). Thus, the additive effects of 5-fluorouracil and NVP-CGM097 on GOT1 cell proliferation seem to be mediated by additive effects on the MDM2-p53-p21-Rb-E2F1 axis (Fig. 5).

Also additive effects of the MDM2 inhibitor NVPCGM097 and temozolomide on decreasing p53 $3^{\text {wild type }}$ GOT1 cell viability were observed (Fig. 4a). The additive effects of NVP-CGM097 and temozolomide in p53 ${ }^{\text {wild type }}$ GOT1 cells might partly be explained by additive increasing effects on p53 $3^{\text {wild type }}$ expression (Fig. 6). However, further studies are necessary to elucidate these mechanisms.

Low/high MGMT expression status is an established risk factor for sensitivity/resistance to temozolomide in glioblastomas [96]. Similarly, in NETs, low MGMT expression [51, 52] or MGMT promoter hypermethylation [97] is associated with a higher sensitivity to alkylating chemotherapeutics such as temozolomide. The MDM2 inhibitor ISA27 and temozolomide have been reported to exert synergistic antiproliferative effects on human glioblastoma multiforme [53]. Expression of p53 $3^{\text {wild type }}$ has been reported to downregulate MGMT in glioblastoma [54-57]. Increasing the expression of p53 [58] or PUMA [98] has been reported to sensitize glioblastoma cells to temozolomide. A Western blot analysis of the expression level of MGMT in the BON1, NCI-H727, and GOT1 NET cell lines demonstrated that there was no detectable level of MGMT expression (Fig. 1) and that, accordingly, all the 3 cell lines tested were responsive to temozolomide (Fig. 4). As there was no detectable expression of MGMT in GOT1 cells, any putative effects of MDM2 inhibition and p53 ${ }^{\text {wild type }}$ expression could not be investigated in this in vitro model.

Also additive effects of the MDM2 inhibitor NVPCGM097 and everolimus (RAD001) on decreasing p53 ${ }^{\text {wild type }}$ GOT1 cell viability were observed (Fig. 4a).
The additive effects of NVP-CGM097 and everolimus (RAD001) on p53 $3^{\text {wild type }}$ GOT1 cells might partly be explained by additive inhibiting effects on phospho-Rb expression (Fig. 6). Similarly, rapamycin was recently reported to downregulate $\mathrm{Rb}$ phosphorylation in human breast cancer cell lines [63]. However, further studies are necessary to elucidate these mechanisms.

Everolimus (RAD001) did not show any significant effects on the expression levels of pMDM2, MDM2, p53, or p21 (Fig. 5). In contrast to our data, negative effects of rapamycin on MDM2 protein levels have been reported $[59,60]$. Inhibition of the Akt1 and Akt3 isoforms decreases pMDM2 levels [99].

Antitumoral effects of the somatostatin analogs octreotide and lanreotide in patients with NETs were proven in clinical phase III studies [64-67] and are well established in clinical treatment guidelines [68]. We previously demonstrated that GOT1 cells express somatostatin receptor subtype 2 mRNA [69], and GOT1 cell tumors in murine xenografts are a well-established model for somatostatin receptor-mediated peptide receptor radiotherapy with $\left[{ }^{177} \mathrm{Lu}-\mathrm{DOTA}{ }^{0}, \mathrm{Tyr}^{3}\right]$ octreotate or $\left[{ }^{177} \mathrm{Lu}\right.$ DOTA $^{0}, \mathrm{Tyr}^{3}$ ] octreotide [70-73]. However, GOT1 cells do not respond to treatment with somatostatin type 2 analogs such as BIM-23023 [69] or octreotide (see Results). Thus, GOT1 cells do not seem to be a valid model for examining effects of somatostatin analogs in vitro.

Current chemotherapy regimens for NET include 5 -fluorouracil/streptozotocin [4, 7, 100, 101], temozolomide or capecitabine/temozolomide $[4,7,102]$, and capecitabine/bevacizumab $[7,103]$ as well as molecular targeted therapy with the mTOR inhibitor everolimus $[7,8,10]$ and the multi-tyrosine kinase inhibitor sunitinib $[7,9]$. Based on our in vitro results, combined regimens of MDM2 inhibitors with 5-fluorouracil, temozolomide, or everolimus should be further investigated in NETs.

In conclusion, the novel MDM2 inhibitor NVPCGM097 shows antitumoral efficacy in human neuroendocrine $\mathrm{p} 53^{\text {wild type }}$ GOT1 tumor cells. In addition, NVPCGM097 demonstrates additive antitumoral effects in combination with 5-fluororuacil, temozolomide, or everolimus on $\mathrm{p} 53^{\text {wild type }} \mathrm{GOT} 1$ tumor cells. The additive effects of NVP-CGM097 and 5-fluorouracil seem mediated by a synergistic increase in p53, PUMA, and p21 expression. As TP53 gene mutation is a rare event in NETs in vivo [21, 22], MDM2 inhibition and reexpression of p53 $3^{\text {wild type }}$ seems a promising therapeutic strategy in NETs. Further preclinical studies and clinical trials should investigate the potential role of MDM2 inhibitors in combination regimens for NETs.
16

Neuroendocrinology 2018;106:1-19 DOI: $10.1159 / 000453369$
Reuther et al. 


\section{Acknowledgment}

This work contains parts of the unpublished doctoral thesis of C.R. This study has been funded within NeoExNET (Network of Excellence for Neuroendocrine Tumors in Munich). NeoExNET is a national database for the evaluation of diagnostics, treatments, and outcomes in NETs. NeoExNET is supported by the German Federal Ministry of Education and Research (BMBF; $\mathrm{m}^{4}$ Cluster - Personalized Medicine and Targeted Therapies Leading-Edge Cluster Munich, 16EX1221J, 01EX1020E) and by an unrestricted educational grant from Novartis Pharma $\mathrm{GmbH}$, Nürnberg, Germany. Members of the NeoExNET study group include the Principal Investigator Günter K. Stalla (Max Planck
Institute of Psychiatry, Munich) and the Steering Committee: Felix Beuschlein (Ludwig Maximilian University, Munich), C.J.A. (Ludwig Maximilian University, Munich), and Klaus A. Kuhn (Technische Universität München, Munich).

\section{Disclosure Statement}

C.J.A. has received research contracts (Ipsen, Novartis), lecture honoraria (Ipsen, Novartis, Pfizer, Amgen, Roche, and Falk), and advisory board honoraria (Novartis). The authors declare that there is no conflict of interest that would prejudice the impartiality of this scientific work.

\section{References}

1 Frilling A, Akerström G, Falconi M, Pavel M, Ramos J, Kidd M, et al: Neuroendocrine tumor disease: an evolving landscape. Endocr Relat Cancer 2012;19:R163-R185.

2 Öberg K, Casanovas O, Castaño JP, Chung D, Delle Fave G, Denèfle $P$, et al: Molecular pathogenesis of neuroendocrine tumors: implications for current and future therapeutic approaches. Clin Cancer Res 2013;19:28422849.

3 Öberg K, Hellman P, Ferolla P, Papotti M; ESMO Guidelines Working Group: Neuroendocrine bronchial and thymic tumors: ESMO Clinical Practice Guidelines for diagnosis, treatment and follow-up. Ann Oncol 2012; 23(suppl 7):vii120-vii123.

4 Öberg K, Knigge U, Kwekkeboom D, Perren A; ESMO Guidelines Working Group: Neuroendocrine gastro-entero-pancreatic tumors: ESMO Clinical Practice Guidelines for diagnosis, treatment and follow-up. Ann Oncol 2012;23(suppl 7):vii124-vii130.

5 Pavel M: Translation of molecular pathways into clinical trials of neuroendocrine tumors. Neuroendocrinology 2013;97:99-112.

6 Dong M, Phan AT, Yao JC: New strategies for advanced neuroendocrine tumors in the era of targeted therapy. Clin Cancer Res 2012;18: 1830-1836.

7 Kulke MH, Shah MH, Benson AB 3rd, Bergsland E, Berlin JD, Blaszkowsky LS, et al: Neuroendocrine tumors, version 1.2015 . J Natl Compr Canc Netw 2015;13:78-108.

8 Yao JC, Shah MH, Ito T, Bohas CL, Wolin EM, Van Cutsem E, et al: Everolimus for advanced pancreatic neuroendocrine tumors. $\mathrm{N}$ Engl J Med 2011;364:514-523.

9 Raymond E, Dahan L, Raoul J-L, Bang Y-J, Borbath I, Lombard-Bohas C, et al: Sunitinib malate for the treatment of pancreatic neuroendocrine tumors. N Engl J Med 2011;364: 501-513.

10 Yao JC, Fazio N, Singh S, Buzzoni R, Carnaghi $\mathrm{C}$, Wolin E, et al: Everolimus for the treatment of advanced, non-functional neuroendocrine tumours of the lung or gastrointestinal tract
(RADIANT-4): a randomised, placebo-controlled, phase 3 study. Lancet 2016;387:968977.

11 Brown CJ, Cheok CF, Verma CS, Lane DP: Reactivation of p53: from peptides to small molecules. Trends Pharmacol Sci 2011;32. 53-62.

12 Li Q, Lozano G: Molecular pathways: targeting $\mathrm{Mdm} 2$ and $\mathrm{Mdm} 4$ in cancer therapy. Clin Cancer Res 2013;19:34-41.

13 Zak K, Pecak A, Rys B, Wladyka B, Dömling A, Weber L, et al: Mdm2 and MdmX inhibitors for the treatment of cancer: a patent review (2011-present). Expert Opin Ther Pat 2013;23:425-448.

14 Burgess A, Chia KM, Haupt S, Thomas D, Haupt Y, Lim E: Clinical overview of MDM2/X-targeted therapies. Front Oncol 2016;6:7.

15 Jeay S, Gaulis S, Ferretti S, Bitter H, Ito M, Valat T, et al: A distinct p53 target gene set predicts for response to the selective p53HDM2 inhibitor NVP-CGM097. Elife 2015; 4:e06498.

16 Valat T, Masuya K, Baysang F, Albrecht G, Buschmann N, Erdmann D, et al: Mechanistic study of NVP-CGM097: a potent, selective and species specific inhibitor of p53-Mdm2. Cancer Res 2014;74(suppl):abstract 1798.

17 Masuya K, Furet P, Stutz S, Holzer P, PissotSoldmann C, Buschmann N, et al: Discovery of CGM097 as a novel Mdm2 inhibitor. Cancer Res 2014;74(suppl):abstract DDT01-01

18 Briest F, Grabowski P: The p53 network as therapeutic target in gastroenteropancreatic neuroendocrine neoplasms. Cancer Treat Rev 2015;41:423-430.

19 Briest F, Grass I, Christen F, Lewens F, Freitag $\mathrm{H}$, Kaemmerer D, et al: Role of MDM2 as therapeutic target in gastroenteropancreatic neuroendocrine neoplasms (GEP-NENs) (abstract 455). Eur J Cancer 2014;50(suppl 6): 149 .

$20 \mathrm{Hu}$ W, Feng Z, Modica I, Klimstra DS, Song L, Allen PJ, et al: Gene amplifications in welldifferentiated pancreatic neuroendocrine tu- mors inactivate the $\mathrm{p} 53$ pathway. Genes Cancer 2010;1:360-368.

21 Banck MS, Kanwar R, Kulkarni AA, Boora GK, Metge F, Kipp BR, et al: The genomic landscape of small intestine neuroendocrine tumors. J Clin Invest 2013;123:2502-2508.

22 Jiao Y, Shi C, Edil BH, de Wilde RF, Klimstra DS, Maitra A, et al: DAXX/ATRX, MEN1, and mTOR pathway genes are frequently altered in pancreatic neuroendocrine tumors. Science 2011;331:1199-1203.

23 Nenutil R, Smardova J, Pavlova S, Hanzelkova Z, Muller P, Fabian P, et al: Discriminating functional and non-functional p53 in human tumours by p53 and MDM2 immunohistochemistry. J Pathol 2005;207:251-259.

24 Bellini MF, Cadamuro ACT, Succi M, Proença MA, Silva AE: Alterations of the TP53 gene in gastric and esophageal carcinogenesis. J Biomed Biotechnol 2012;2012:891961.

25 Watanabe G, Ishida T, Furuta A, Takahashi S, Watanabe $M$, Nakata $H$, et al: Combined immunohistochemistry of PLK1, p21, and p53 for predicting TP53 status: an independent prognostic factor of breast cancer. Am J Surg Pathol 2015;39:1026-1034.

26 Takizawa N, Ohishi Y, Hirahashi M, Takahashi S, Nakamura K, Tanaka M, et al: Molecular characteristics of colorectal neuroendocrine carcinoma; similarities with adenocarcinoma rather than neuroendocrine tumor. Hum Pathol 2015;46:1890-1900.

27 Yildirim M, Kaya V, Demirpence O, Gunduz S, Bozcuk H: Prognostic significance of p53 in gastric cancer: a meta-analysis. Asian Pac J Cancer Prev 2015;16:327-332.

28 Wei K, Jiang L, Wei Y, Wang Y, Qian X, Dai $\mathrm{Q}$, et al: The prognostic significance of $\mathrm{p} 53$ expression in gastric cancer: a meta-analysis. J Cancer Res Clin Oncol 2015;141:735-748.

29 McCormick Matthews LH, Noble F, Tod J, Jaynes E, Harris S, Primrose JN, et al: Systematic review and meta-analysis of immunohistochemical prognostic biomarkers in resected oesophageal adenocarcinoma. Br J Cancer 2015;113:107-118.
NVP-CGM097 Inhibits Tumor Cell Proliferation in NET Cell Line GOT1
Neuroendocrinology 2018;106:1-19 DOI: $10.1159 / 000453369$ 
30 Zhan P, Ji Y-N: Prognostic significance of TP53 expression for patients with hepatocellular carcinoma: a meta-analysis. Hepatobiliary Surg Nutr 2014;3:11-17.

31 Kimıloğlu Şahan E, Erdoğan N, Ulusoy İ, Samet E, Akyıldız İğdem A, Gönüllü D: P53, KI-67, CD117 expression in gastrointestinal and pancreatic neuroendocrine tumours and evaluation of their correlation with clinicopathological and prognostic parameters. Turk J Gastroenterol 2015;26:104-111.

32 Naranjo Gómez JM, Bernal JF, Arranz PG, Fernández SL, Roman JJ: Alterations in the expression of p53, KLF4, and p21 in neuroendocrine lung tumors. Arch Pathol Lab Med 2014;138:936-942.

33 Swarts DRA, Ramaekers FCS, Speel E-JM: Molecular and cellular biology of neuroendocrine lung tumors: evidence for separate biological entities. Biochim Biophys Acta 2012; 1826:255-271.

34 George J, Lim JS, Jang SJ, Cun Y, Ozretić L, Kong G, et al: Comprehensive genomic profiles of small cell lung cancer. Nature 2015; 524:47-53.

35 Saiki AY, Caenepeel S, Cosgrove E, Su C, Boedigheimer M, Oliner JD: Identifying the determinants of response to MDM2 inhibition. Oncotarget 2015;6:7701-7712.

36 Lee HS, Chen M, Kim JH, Kim WH, Ahn S, Maeng K, et al: Analysis of 320 gastroenteropancreatic neuroendocrine tumors identifies TS expression as independent biomarker for survival. Int J Cancer 2014;135:128-137.

37 Spampatti M, Vlotides G, Spöttl G, Maurer J, Göke B, Auernhammer CJ: Aspirin inhibits cell viability and mTOR downstream signaling in gastroenteropancreatic and bronchopulmonary neuroendocrine tumor cells. World J Gastroenterol 2014;20:10038-10049.

38 Evers BM, Townsend CM Jr, Upp JR, Allen E, Hurlbut SC, Kim SW, et al: Establishment and characterization of a human carcinoid in nude mice and effect of various agents on tumor growth. Gastroenterology 1991;101:303311.

39 Babu V, Paul N, Yu R: Animal models and cell lines of pancreatic neuroendocrine tumors. Pancreas 2013;42:912-923.

40 Kölby L, Bernhardt P, Ahlman H, Wängberg B, Johanson V, Wigander A, et al: A transplantable human carcinoid as model for somatostatin receptor-mediated and amine transporter-mediated radionuclide uptake. Am J Pathol 2001;158:745-755.

41 Schuller HM, Falzon M, Gazdar AF, Hegedus $\mathrm{T}$ : Cell type-specific differences in metabolic activation of $\mathrm{N}$-nitrosodiethylamine by human lung cancer cell lines. IARC Sci Publ 1987;84:138-140.

42 Cakir M, Grossman A: The molecular pathogenesis and management of bronchial carcinoids. Expert Opin Ther Targets 2011;15: 457-491.

43 Reuther C, Heinzle V, Spampatti M, Vlotides G, de Toni E, Spöttl G, et al: Cabozantinib and tivantinib, but not INC280, induce anti-pro- liferative and anti-migratory effects in human neuroendocrine tumour cells in vitro: evidence for "off-target" effects not mediated by c-Met inhibition. Neuroendocrinology 2016; 103:383-401.

44 Petitjean A, Mathe E, Kato S, Ishioka C, Tavtigian SV, Hainaut $P$, et al: Impact of mutant p53 functional properties on TP53 mutation patterns and tumor phenotype: Lessons from recent developments in the IARC TP53 database. Hum Mutat 2007;28:622-629.

$45 \mathrm{Du}$ W, Wu J, Walsh EM, Zhang Y, Chen CY, Xiao Z-XJ: Nutlin-3 affects expression and function of retinoblastoma protein: role of retinoblastoma protein in cellular response to nutlin-3. J Biol Chem 2009;284:26315-26321.

46 Laine A, Westermarck J: Molecular pathways: harnessing E2F1 regulation for prosenescence therapy in p53-defective cancer cells. Clin Cancer Res 2014;20:3644-3650.

47 Brooks CL, Li M, Hu M, Shi Y, Gu W: The p53-Mdm2-HAUSP complex is involved in p53 stabilization by HAUSP. Oncogene 2007; 26:7262-7266.

48 Kon N, Kobayashi Y, Li M, Brooks CL, Ludwig T, Gu W: Inactivation of HAUSP in vivo modulates p53 function. Oncogene 2010;29: 1270-1279.

49 Tang J, Qu L, Pang M, Yang X: Daxx is reciprocally regulated by Mdm2 and Hausp. Biochem Biophys Res Commun 2010;393:542545.

50 Sun X-X, Dai M-S, Lu H: 5-Fluorouracil activation of p53 involves an MDM2-ribosomal protein interaction. J Biol Chem 2007;282: 8052-8059.

51 Kulke MH, Hornick JL, Frauenhoffer C, Hooshmand S, Ryan DP, Enzinger PC, et al: $\mathrm{O}^{6}$-methylguanine DNA methyltransferase deficiency and response to temozolomidebased therapy in patients with neuroendocrine tumors. Clin Cancer Res 2009; 15:338345.

52 Walter T, van Brakel B, Vercherat C, Hervieu $\mathrm{V}$, Forestier J, Chayvialle J-A, et al: $O^{6}$-methylguanine-DNA methyltransferase status in neuroendocrine tumours: prognostic relevance and association with response to alkylating agents. Br J Cancer 2015;112:523-531.

53 Costa B, Bendinelli S, Gabelloni P, Da Pozzo E, Daniele S, Scatena F, et al: Human glioblastoma multiforme: $\mathrm{p} 53$ reactivation by a novel MDM2 inhibitor. PLoS One 2013;8:e72281.

54 Bocangel D, Sengupta S, Mitra S, Bhakat KK: p53-mediated down-regulation of the human DNA repair gene $O^{6}$-methylguanine-DNA methyltransferase $(M G M T)$ via interaction with Sp1 transcription factor. Anticancer Res 2009;29:3741-3750.

55 Hermisson M, Klumpp A, Wick W, Wischhusen J, Nagel G, Roos W, et al: $O^{6}$-methylguanine DNA methyltransferase and p53 status predict temozolomide sensitivity in human malignant glioma cells. J Neurochem 2006;96: 766-776.

56 Natsume A, Ishii D, Wakabayashi T, Tsuno T, Hatano H, Mizuno M, et al: IFN- $\beta$ down-reg- ulates the expression of DNA repair gene $M G M T$ and sensitizes resistant glioma cells to temozolomide. Cancer Res 2005;65:75737579 .

57 Natsume A, Wakabayashi T, Ishii D, Maruta $\mathrm{H}$, Fujii M, Shimato S, et al: A combination of IFN- $\beta$ and temozolomide in human glioma xenograft models: implication of p53-mediated MGMT downregulation. Cancer Chemother Pharmacol 2008;61:653-659.

58 Kim S-S, Rait A, Kim E, Pirollo KF, Nishida $\mathrm{M}$, Farkas N, et al: A nanoparticle carrying the p53 gene targets tumors including cancer stem cells, sensitizes glioblastoma to chemotherapy and improves survival. ACS Nano 2014;8:5494-5514.

59 Kao C-L, Hsu H-S, Chen H-W, Cheng T-H: Rapamycin increases the $\mathrm{p} 53 / \mathrm{MDM} 2$ protein ratio and p53-dependent apoptosis by translational inhibition of $m d m 2$ in cancer cells. Cancer Lett 2009;286:250-259.

$60 \mathrm{Du}$ W, Yi Y, Zhang H, Bergholz J, Wu J, Ying $\mathrm{H}$, et al: Rapamycin inhibits IGF-1-mediated up-regulation of MDM2 and sensitizes cancer cells to chemotherapy. PLoS One 2013; 8:e63179.

61 Goudarzi KM, Nistér M, Lindström MS: mTOR inhibitors blunt the p53 response to nucleolar stress by regulating RPL11 and MDM2 levels. Cancer Biol Ther 2014;15: 1499-1514.

62 Selvarajah J, Nathawat K, Moumen A, Ashcroft M, Carroll VA: Chemotherapy-mediated p53-dependent DNA damage response in clear cell renal cell carcinoma: role of the mTORC1/2 and hypoxia-inducible factor pathways. Cell Death Dis 2013;4:e865.

63 Chatterjee A, Mukhopadhyay S, Tung K, Patel D, Foster DA: Rapamycin-induced G1 cell cycle arrest employs both TGF- $\beta$ and Rb pathways. Cancer Lett 2015;360:134-140.

64 Rinke A, Müller H-H, Schade-Brittinger C, Klose K-J, Barth P, Wied M, et al: Placebocontrolled, double-blind, prospective, randomized study on the effect of octreotide LAR in the control of tumor growth in patients with metastatic neuroendocrine midgut tumors: a report from the PROMID Study Group. J Clin Oncol 2009;27:4656-4663.

65 Rinke A, Wittenberg M, Schade-Brittinger C, Aminossadati B, Ronicke E, Gress TM, et al: Placebo controlled, double blind, prospective, randomized study on the effect of octreotide LAR in the control of tumor growth in patients with metastatic neuroendocrine midgut tumors (PROMID): results of long-term survival. Neuroendocrinology 2017;104:26-32.

66 Caplin ME, Pavel M, Ćwikła JB, Phan AT, Raderer M, Sedláčková E, et al: Lanreotide in metastatic enteropancreatic neuroendocrine tumors. N Engl J Med 2014;371:224-233.

67 Caplin M, Pavel M, Ćwikła JB, Phan A, Raderer M, Sedláčková E, et al: Anti-tumour effects of lanreotide for pancreatic and intestinal neuroendocrine tumours: the CLARINET open-label extension study. Endocr Relat Cancer 2016;23:191-199. 
68 Pavel M, O’Toole D, Costa F, Capdevila J, Gross D, Kianmanesh R, et al: ENETS Consensus Guidelines update for the management of distant metastatic disease of intestinal, pancreatic, bronchial neuroendocrine neoplasms (NEN) and NEN of unknown primary site. Neuroendocrinology 2016;103: 172-185.

69 Zitzmann K, Andersen S, Vlotides G, Spöttl G, Zhang S, Datta R, et al: The novel somatostatin receptor 2 /dopamine type 2 receptor chimeric compound BIM-23A758 decreases the viability of human GOT1 midgut carcinoid cells. Neuroendocrinology 2013;98:128136.

70 Nilsson O, Kölby L, Bernhardt P, ForssellAronsson E, Johanson V, Ahlman H: GOT1 xenografted to nude mice: a unique model for in vivo studies on SSTR-mediated radiation therapy of carcinoid tumors. Ann NY Acad Sci 2004;1014:275-279.

71 Kölby L, Bernhardt P, Johanson V, Schmitt A, Ahlman H, Forssell-Aronsson E, et al: Successful receptor-mediated radiation therapy of xenografted human midgut carcinoid tumour. Br J Cancer 2005;93:1144-1151.

72 Swärd C, Bernhardt P, Johanson V, Schmitt A, Ahlman H, Stridsberg M, et al: Comparison of $\left[{ }^{177} \mathrm{Lu}-\mathrm{DOTA}^{0}, \mathrm{Tyr}^{3}\right]$-octreotate and $\left[{ }^{177} \mathrm{Lu}-\mathrm{DOTA}{ }^{0}, \mathrm{Tyr}^{3}\right]$-octreotide for receptormediated radiation therapy of the xenografted human midgut carcinoid tumor GOT1. Cancer Biother Radiopharm 2008;23:114120.

73 Oddstig J, Bernhardt P, Lizana H, Nilsson O, Ahlman H, Kölby L, et al: Inhomogeneous activity distribution of ${ }^{177} \mathrm{Lu}$-DOTA ${ }^{0}-\mathrm{Tyr}^{3}$-octreotate and effects on somatostatin receptor expression in human carcinoid GOT1 tumors in nude mice. Tumour Biol 2012;33:229-239.

74 Canon J, Osgood T, Olson SH, Saiki AY, Robertson R, Yu D, et al: The MDM2 inhibitor AMG 232 demonstrates robust antitumor efficacy and potentiates the activity of p53inducing cytotoxic agents. Mol Cancer Ther 2015;14:649-658.

75 Vandamme T, Peeters M, Dogan F, Pauwels P, Van Assche E, Beyens M, et al: Wholeexome characterization of pancreatic neuroendocrine tumor cell lines BON-1 and QGP1. J Mol Endocrinol 2015;54:137-147.

76 Engelmann D, Pützer BM: Emerging from the shade of $\mathrm{p} 53$ mutants: $\mathrm{N}$-terminally truncated variants of the p53 family in EMT signaling and cancer progression. Sci Signal 2014;7:re9.

77 Surget S, Khoury MP, Bourdon J-C: Uncovering the role of p53 splice variants in human malignancy: a clinical perspective. Onco Targets Ther 2013;7:57-68.

78 Boora GK, Kanwar R, Kulkarni AA, Pleticha J, Ames M, Schroth G, et al: Exome-level comparison of primary well-differentiated neuroendocrine tumors and their cell lines. Cancer Genet 2015;208:374-381.
79 Vandamme T, Beyens M, Peeters M, Van Camp G, de Beeck KO: Next generation exome sequencing of pancreatic neuroendocrine tumor cell lines BON-1 and QGP-1 reveals different lineages. Cancer Genet 2015; 208:523.

80 Dick FA, Rubin SM: Molecular mechanisms underlying RB protein function. Nat Rev Mol Cell Biol 2013;14:297-306.

81 Gillam MP, Nimbalkar D, Sun L, Christov K, Ray D, Kaldis P, et al: MEN1 tumorigenesis in the pituitary and pancreatic islet requires $C d k 4$ but not Cdk2. Oncogene 2015;34:932-938.

82 Tang LH, Contractor T, Clausen R, Klimstra DS, Du Y-CN, Allen PJ, et al: Attenuation of the retinoblastoma pathway in pancreatic neuroendocrine tumors due to increased cdk4/cdk6. Clin Cancer Res 2012;18:46124620 .

83 Picksley SM, Lane DP: The p53-mdm2 autoregulatory feedback loop: a paradigm for the regulation of growth control by p53? Bioessays 1993;15:689-690.

84 Wu X, Bayle JH, Olson D, Levine AJ: The p53$m d m-2$ autoregulatory feedback loop. Genes Dev 1993;7:1126-1132.

85 Freedman DA, Wu L, Levine AJ: Functions of the MDM2 oncoprotein. Cell Mol Life Sci 1999;55:96-107.

86 Holzer P, Masuya K, Furet P, Kallen J, ValatStachyra T, Ferretti S, et al: Discovery of a dihydroisoquinolinone derivative (NVPCGM097): a highly potent and selective MDM2 inhibitor undergoing phase 1 clinical trials in p53wt tumors. J Med Chem 2015;58: 6348-6358.

87 Weisberg E, Halilovic E, Cooke VG, Nonami A, Ren T, Sanda T, et al: Inhibition of wildtype p53-expressing AML by the novel small molecule HDM2 inhibitor CGM097. Mol Cancer Ther 2015;14:2249-2259.

88 Hay TJ, Meek DW: Multiple sites of in vivo phosphorylation in the MDM2 oncoprotein cluster within two important functional domains. FEBS Lett 2000;478:183-186.

89 Mayo LD, Donner DB: A phosphatidylinositol 3-kinase/Akt pathway promotes translocation of Mdm2 from the cytoplasm to the nucleus. Proc Natl Acad Sci USA 2001;98: 11598-11603.

90 Zhou BP, Liao Y, Xia W, Zou Y, Spohn B, Hung MC: HER-2/neu induces p53 ubiquitination via Akt-mediated MDM2 phosphorylation. Nat Cell Biol 2001;3:973-982.

91 Tang J, Qu L-K, Zhang J, Wang W, Michaelson JS, Degenhardt YY, et al: Critical role for Daxx in regulating Mdm2. Nat Cell Biol 2006; 8:855-862.

92 Heaphy CM, de Wilde RF, Jiao Y, Klein AP, Edil BH, Shi C, et al: Altered telomeres in tumors with ATRX and DAXX mutations. Science 2011;333:425.
93 Tang M, Li Y, Zhang Y, Chen Y, Huang W, Wang D, et al: Disease mutant analysis identifies a new function of DAXX in telomerase regulation and telomere maintenance. J Cell Sci 2015;128:331-341.

94 Marinoni I, Kurrer AS, Vassella E, Dettmer M, Rudolph T, Banz V, et al: Loss of DAXX and ATRX are associated with chromosome instability and reduced survival of patients with pancreatic neuroendocrine tumors. Gastroenterology 2014;146:453-460.e5.

95 Brazina J, Svadlenka J, Macurek L, Andera L, Hodny Z, Bartek J, et al: DNA damage-induced regulatory interplay between DAXX, p53, ATM kinase and Wip1 phosphatase. Cell Cycle 2015;14:375-387.

96 Jiang G, Jiang A-J, Xin Y, Li L-T, Cheng Q, Zheng J-N: Progression of $\mathrm{O}^{6}$-methylguanine-DNA methyltransferase and temozolomide resistance in cancer research. Mol Biol Rep 2014;41:6659-6665.

97 Schmitt AM, Pavel M, Rudolph T, Dawson H, Blank A, Komminoth P, et al: Prognostic and predictive roles of MGMT protein expression and promoter methylation in sporadic pancreatic neuroendocrine neoplasms. Neuroendocrinology 2014;100:35-44.

98 Miao W, Liu X, Wang H, Fan Y, Lian S, Yang $X$, et al: p53 upregulated modulator of apoptosis sensitizes drug-resistant U251 glioblastoma stem cells to temozolomide through enhanced apoptosis. Mol Med Rep 2015;11: 4165-4173.

99 Zitzmann K, Vlotides G, Brand S, Lahm H, Spöttl G, Göke B, et al: Perifosine-mediated Akt inhibition in neuroendocrine tumor cells: role of specific Akt isoforms. Endocr Relat Cancer 2012;19:423-434.

100 Auernhammer CJ, Göke B: Therapeutic strategies for advanced neuroendocrine carcinomas of jejunum/ileum and pancreatic origin. Gut 2011;60:1009-1021.

101 Dilz L-M, Denecke T, Steffen IG, Prasad V, von Weikersthal LF, Pape U-F, et al: Streptozocin/5-fluorouracil chemotherapy is associated with durable response in patients with advanced pancreatic neuroendocrine tumours. Eur J Cancer 2015;51:12531262.

102 Abdel-Rahman O, Fouad M: Temozolomide-based combination for advanced neuroendocrine neoplasms: a systematic review of the literature. Future Oncol 2015;11: 1275-1290.

103 Mitry E, Walter T, Baudin E, Kurtz J-E, Ruszniewski P, Dominguez-Tinajero S, et al: Bevacizumab plus capecitabine in patients with progressive advanced well-differentiated neuroendocrine tumors of the gastro-intestinal (GI-NETs) tract (BETTER trial) - a phase II non-randomised trial. Eur J Cancer 2014;50:3107-3115. 